\title{
Air-sea fluxes of greenhouse gases and oxygen in the northern Benguela Current region during upwelling events
}

\author{
Eric J. Morgan ${ }^{1, a}$, Jost V. Lavric ${ }^{1}$, Damian L. Arévalo-Martínez ${ }^{2}$, Hermann W. Bange ${ }^{2}$, Tobias Steinhoff ${ }^{2}$, \\ Thomas Seifert ${ }^{1}$, and Martin Heimann ${ }^{1,3}$ \\ ${ }^{1}$ Biogeochemical Systems Department, Max Planck Institute for Biogeochemistry, Jena, Germany \\ ${ }^{2}$ GEOMAR Helmholtz Centre for Ocean Research, Kiel, Germany \\ ${ }^{3}$ Institute for Atmospheric and Earth System Research (INAR)/Physics, University of Helsinki, Helsinki, Finland \\ ${ }^{a}$ now at: Scripps Institution of Oceanography, University of California, San Diego, La Jolla, CA, USA
}

Correspondence: Eric J. Morgan (ejmorgan@ucsd.edu)

Received: 20 March 2019 - Discussion started: 26 March 2019

Revised: 13 September 2019 - Accepted: 18 September 2019 - Published: 21 October 2019

\begin{abstract}
Ground-based atmospheric observations of $\mathrm{CO}_{2}$, $\delta\left(\mathrm{O}_{2} / \mathrm{N}_{2}\right), \mathrm{N}_{2} \mathrm{O}$, and $\mathrm{CH}_{4}$ were used to make estimates of the air-sea fluxes of these species from the Lüderitz and Walvis Bay upwelling cells in the northern Benguela region, during upwelling events. Average flux densities $( \pm 1 \sigma)$ were $0.65 \pm 0.4 \mu \mathrm{mol} \mathrm{m}^{-2} \mathrm{~s}^{-1}$ for $\mathrm{CO}_{2},-5.1 \pm 2.5 \mu \mathrm{mol} \mathrm{m}^{-2} \mathrm{~s}^{-1}$ for $\mathrm{O}_{2}$ (as APO), $0.61 \pm 0.5 \mathrm{nmol} \mathrm{m}^{-2} \mathrm{~s}^{-1}$ for $\mathrm{N}_{2} \mathrm{O}$, and $4.8 \pm 6.3 \mathrm{nmol} \mathrm{m}^{-2} \mathrm{~s}^{-1}$ for $\mathrm{CH}_{4}$. A comparison of our topdown (i.e., inferred from atmospheric anomalies) flux estimates with shipboard-based measurements showed that the two approaches agreed within $\pm 55 \%$ on average, though the degree of agreement varied by species and was best for $\mathrm{CO}_{2}$. Since the top-down method overestimated the flux density relative to the shipboard-based approach for all species, we also present flux density estimates that have been tuned to best match the shipboard fluxes. During the study, upwelling events were sources of $\mathrm{CO}_{2}, \mathrm{~N}_{2} \mathrm{O}$, and $\mathrm{CH}_{4}$ to the atmosphere. $\mathrm{N}_{2} \mathrm{O}$ fluxes were fairly low, in accordance with previous work suggesting that the evasion of this gas from the Benguela is smaller than for other eastern boundary upwelling systems (EBUS). Conversely, $\mathrm{CH}_{4}$ release was quite high for the marine environment, a result that supports studies that indicated a large sedimentary source of $\mathrm{CH}_{4}$ in the Walvis Bay area. These results demonstrate the suitability of atmospheric time series for characterizing the temporal variability of upwelling events and their influence on the overall marine greenhouse gas (GHG) emissions from the northern Benguela region.
\end{abstract}

\section{Introduction}

Coastal margins, particularly those associated with the upwelling of nutrient-rich subsurface waters, are biogeochemically active regions (Levin et al., 2015). The air-sea fluxes of greenhouse gases (GHGs, referring to the long-lived greenhouse gases $\mathrm{CO}_{2}, \mathrm{~N}_{2} \mathrm{O}$, and $\mathrm{CH}_{4}$ ) from or to such systems can vary markedly, both spatially and temporally (Torres et al., 1999; Naqvi et al., 2010; Evans et al., 2011; Reimer et al., 2013; Capone and Hutchins, 2013). This is because both the occurrence and intensity of coastal upwelling events are variable in nature, as they are forced by surface winds that occur under specific synoptic conditions; even large events happen only on a timescale of days (Blanke et al., 2005; Goubanova et al., 2013; Desbiolles et al., 2014a, b). The sporadic nature of upwelling implies that observations made during short-term campaigns may not capture the full range of flux variability.

Upwelled water is usually colder than the surrounding surface water, which means that the solubility of dissolved gases will decrease with increasing temperature as water masses warm at the surface. A competing influence for $\mathrm{CO}_{2} \mathrm{ex}-$ ists in that the supply of inorganic nutrients from an upwelling event can lead to blooms of phytoplankton and a net drawdown of atmospheric $\mathrm{CO}_{2}$. For $\mathrm{O}_{2}$, the ventilation of deeper water masses can drive a net flux into the ocean, or net productivity can create oversaturation of dissolved $\mathrm{O}_{2}$. Hence, coastal upwelling regions can oscillate between being sources and sinks of $\mathrm{O}_{2}$ and $\mathrm{CO}_{2}$ (Torres et al., 1999; Santana-Casiano et al., 2009; González-Dávila et al., 2009; 
Gregor and Monteiro, 2013; Cao et al., 2014; Evans et al., 2015). Most coastal upwelling systems are also known to be regional hotspots of $\mathrm{N}_{2} \mathrm{O}$ emissions (Bange et al., 2001; Lueker et al., 2003; Cornejo et al., 2006; Bianchi et al., 2012; Arévalo-Martínez et al., 2015; Babbin et al., 2015). Air-sea fluxes of $\mathrm{CH}_{4}$ are less constrained, but may be a significant term in the marine $\mathrm{CH}_{4}$ budget (Rehder et al., 2002; Sansone et al., 2001).

A well-established method of estimating budgets of airsea fluxes for GHGs in upwelling regions is to take wind fields and interpolated or representative surface measurements, use them to calculate a flux density, and scale it up over a selected area. The high variability of air-sea exchange means that determining budgets of air-sea fluxes of GHGs is challenging without a high degree of spatial and temporal sampling. We refer to this in the text as the "bottom-up" approach.

Another approach, and one that sidesteps some of these difficulties, is to use a "top-down method", i.e., using atmospheric measurements to infer fluxes from the surface, using simple models (Lueker et al., 2003; Lueker, 2004; Nevison et al., 2004; Thompson et al., 2007; Yamagishi et al., 2008) or more complex inverse methods (e.g., Rödenbeck et al., 2008). A simple top-down approach has been successfully employed to detect air-sea fluxes of $\mathrm{CO}_{2}, \mathrm{O}_{2}$, and $\mathrm{N}_{2} \mathrm{O}$ from the California Current region from a coastal atmospheric monitoring station at Trinidad Head, California (Lueker et al., 2003; Lueker, 2004; Nevison et al., 2004). This work motivated our own efforts to see whether anomalies related to upwelling events could be seen in continuous observations from an atmospheric measurement site located near the upwelling region in the northern Benguela region, which is one of the least sampled EBUS for air-sea fluxes of GHGs (Nevison et al., 2004; Naqvi et al., 2010; Laruelle et al., 2014).

In this study, 2 years of continuous observations from a ground-based atmospheric observatory for greenhouse gases, the Namib Desert Atmospheric Observatory (NDAO), were utilized to create top-down estimates of the air-sea flux densities of $\mathrm{CO}_{2}, \mathrm{O}_{2}, \mathrm{~N}_{2} \mathrm{O}$, and $\mathrm{CH}_{4}$ from the Lüderitz and Walvis Bay upwelling cells, during upwelling events. We focus on individual upwelling events as we expect them to be distinguishable from other sources of intraseasonal variability based on their apparent stoichiometry in the atmosphere and because there are relatively few observation-based studies from this region, relative to other EBUS. This area of the coastal shelf, stretching from ca. 22 to $28^{\circ} \mathrm{S}$, is subject to the strongest surface winds and upwelling fluxes of water in the region, and surface chlorophyll is at a minimum (Lutjeharms and Meeuwis, 1987; Hagen et al., 2001; Demarcq et al., 2007; Veitch et al., 2009; Hutchings et al., 2009). These estimates were then compared with shipboard measurements from a cruise in the two upwelling centers.

\section{Methods}

\subsection{Atmospheric measurements at the Namib Desert Atmospheric Observatory}

Continuous measurements of $\mathrm{CO}_{2}$, atmospheric oxygen, $\mathrm{N}_{2} \mathrm{O}, \mathrm{CH}_{4}$, and $\mathrm{CO}$ were made at the Namib Desert Atmospheric Observatory (NDAO), a background site located at $23.563^{\circ} \mathrm{S}, 15.045^{\circ} \mathrm{E}$, in the central Namib Desert, at Gobabeb Research and Training Centre. This dataset is provided as a Supplement to this paper, available online at: https: //doi.org/10.5194/bg-16-1-2019-supplement. A full description of the measurement system is given in Morgan et al. (2015). In brief, observations were made at a height of $21 \mathrm{~m}$ above ground level with a Picarro ESP-1000 cavity ringdown spectrometer (CRDS) for $\mathrm{CO}_{2}$ and $\mathrm{CH}_{4}$, a Los Gatos $\mathrm{N}_{2} \mathrm{O} / \mathrm{CO}-23 \mathrm{~d}$ cavity-enhanced absorption spectrometer for $\mathrm{N}_{2} \mathrm{O}$ and $\mathrm{CO}$, and an Oxzilla FC-II dual absolute and differential oxygen analyzer for $\delta\left(\mathrm{O}_{2} / \mathrm{N}_{2}\right)$.

While the Picarro and Los Gatos analyzers measure continuously (data are recorded at approximately 0.5 and $1 \mathrm{~Hz}$, respectively), the Oxzilla analyzer measures the difference between sample air and a reference tank, at a data rate of $0.01 \mathrm{~Hz}$. Calibration of the instruments was done through four working secondary standards and instrument performance was periodically checked with "target" cylinders (i.e., tanks of known mole fraction which are regularly remeasured). Reference gases comprised dry ambient air and were stored in $50 \mathrm{~L}$ aluminum cylinders. Calibrations were run every $123 \mathrm{~h}$ for the Picarro and Los Gatos analyzers and every $71 \mathrm{~h}$ for the Oxzilla analyzer. All measurements were tied to primary standards on the following scales: WMO X2007 for $\mathrm{CO}_{2}$, NOAA 2004 for $\mathrm{CH}_{4}$, NOAA 2006a for $\mathrm{N}_{2} \mathrm{O}$, WMO X2004 for $\mathrm{CO}$, and the Scripps Institution of Oceanography Scale for $\delta\left(\mathrm{O}_{2} / \mathrm{N}_{2}\right)$, as defined on $1 \mathrm{Au}-$ gust 2012.

The average uncertainty for each species during the study period was $0.028 \mathrm{ppm}$ for $\mathrm{CO}_{2}, 6.5$ per meg for $\delta\left(\mathrm{O}_{2} / \mathrm{N}_{2}\right)$, $0.21 \mathrm{ppb}$ for $\mathrm{N}_{2} \mathrm{O}, 0.17 \mathrm{ppb}$ for $\mathrm{CH}_{4}$, and $0.15 \mathrm{ppb}$ for CO. $\mathrm{CO}_{2}, \mathrm{~N}_{2} \mathrm{O}, \mathrm{CH}_{4}$, and $\mathrm{CO}$ are all expressed as dry air mole fractions, in ppb or ppm $\left(1 \mathrm{ppm}=1 \mu \mathrm{mol} \mathrm{mol}^{-1}\right.$; $1 \mathrm{ppb}=1 \mathrm{nmol} \mathrm{mol}{ }^{-1}$ ).

By convention, changes in atmospheric oxygen were quantified as the $\mathrm{O}_{2} / \mathrm{N}_{2}$ ratio relative to a standard, in per meg units (Keeling and Shertz, 1992):

$\delta\left(\mathrm{O}_{2} / \mathrm{N}_{2}\right)=\left(\frac{\left(\mathrm{O}_{2} / \mathrm{N}_{2}\right)_{\text {sample }}}{\left(\mathrm{O}_{2} / \mathrm{N}_{2}\right)_{\text {ref }}}-1\right) \times 10^{6}$.

In order to isolate the influence of air-sea exchanges on $\mathrm{O}_{2} / \mathrm{N}_{2}$, we have employed the use of a data-derived tracer, known as atmospheric potential oxygen (APO), which masks variations of $\mathrm{O}_{2} / \mathrm{N}_{2}$ that are due to terrestrial biosphere exchange (Stephens et al., 1998). Variations in APO are thus primarily due to fossil fuel burning and air-sea gas exchange 
of $\mathrm{O}_{2}$. APO is defined as

$\mathrm{APO}=\delta\left(\mathrm{O}_{2} / \mathrm{N}_{2}\right)+\frac{1.1}{X_{\mathrm{O}_{2}}}\left(\mathrm{CO}_{2}-350\right)$.

Here 1.1 is the nominal global average oxidative ratio (OR; $\Delta \mathrm{O}_{2} / \Delta \mathrm{CO}_{2}$ on a mol/mol basis) for terrestrial photosynthesis and respiration (Severinghaus, 1995), and $X_{\mathrm{O}_{2}}$ is the mole fraction of oxygen in the atmosphere, 0.2095 , as defined by the Scripps $\mathrm{O}_{2}$ Program scale; 350 is a reference $\mathrm{CO}_{2}$ value, and $\mathrm{CO}_{2}$ is the in situ concentration of carbon dioxide, in ppm. APO and $\delta\left(\mathrm{O}_{2} / \mathrm{N}_{2}\right)$ are both expressed in per meg. In some instances it is useful to express APO in molar units that are of the same relative magnitude as the dry air mole fraction in ppm. This conversion is done by multiplying $\delta\left(\mathrm{O}_{2} / \mathrm{N}_{2}\right)$ or APO by $X_{\mathrm{O}_{2}}$. We refer to this unit as parts per million equivalents, or "ppm eq".

\subsection{Remote sensing data}

Following the reasoning of Goubanova et al. (2013), sea surface temperature (SST) data were obtained from the Remote Sensing Systems (http://www.remss.com/, last access: 28 December 2014) data archive. The Tropical Rainfall Measuring Mission (TRMM) Microwave Imager (TMI) daily optimally interpolated SST product was selected. The major advantage of this instrument is its ability to measure SST through clouds, which are considerable over the coast, as the TMI measures frequencies in the microwave region (4$11 \mathrm{GHz}$ ). The drawback of this dataset is that there are no data within $100 \mathrm{~km}$ of the coast. Large upwelling features, however, extend much farther out than this and are readily seen by the TMI (Goubanova et al., 2013). Even with this loss of near-shore data, the data coverage is still superior to that of optical sensors like the Moderate-Resolution Imaging Spectroradiometer (MODIS). The TRMM SST data presented in this work are deseasonalized by subtracting a second harmonic fit to the data, as it showed a strong seasonal cycle which masked some of the intraseasonal variability when plotted as a time series.

Wind speed data for the South Atlantic were also derived from the TMI instrument on the TRMM satellite. This dataset is a level 3 product which gives the $10 \mathrm{~m}$ wind speed over marine areas within the sensor's field of view. The $18.7 \mathrm{GHz}$ channel data product was selected. Like the SST data, a major drawback of this dataset is the absence of data within $100 \mathrm{~km}$ of land.

Two surface chlorophyll products were used, both level 3 binned products that combined data from multiple satellites, accessed through the ESA GlobColour website (http: //www.globcolour.info/, last access: 15 December 2014). The first is denoted CHL1-GSM; this dataset is a merged product of two different sensors (during the time period considered), MODIS and the Visible Infrared Imaging Radiometer Suite (VIIRS). The data are merged using the GarverSiegel-Maritorena (GSM) model, which blends the normal- ized water-leaving radiances instead of $\mathrm{Chl} a$ concentrations (Maritorena and Siegel, 2005). The second product is denoted CHL1-AVW; these data are merged using a weighted average method (AVW). Like CHL1-GSM, it combines data from MODIS and VIIRS for the time frame considered.

\subsection{Atmospheric back-trajectories}

Back-trajectories, which trace the path of a particle from a receptor point backwards in time, provide a history of recent atmospheric transport. Back-trajectories were simulated with the HYbrid Single Particle Lagrangian Integrated Trajectory (HYSPLIT) 4 model (Draxler and Hess, 1997, 1998) from NDAO for $120 \mathrm{~h}$, for the entire time series. A new trajectory was calculated every $6 \mathrm{~h}$, starting at 00:00 UTC, i.e., at 01:00, 07:00, 13:00, and 19:00 local time. The model was run with a spatial resolution of $1^{\circ} \times 1^{\circ}$ and a temporal resolution of $1 \mathrm{~h}$. A vertical cut-off of $10 \mathrm{~km}$ a.g.l. was used. Meteorological fields were obtained from the National Center for Environmental Prediction (NCEP) Global Data Assimilation System (GDAS).

\subsection{Identification of upwelling events and selection of atmospheric anomalies}

A subset of the coastal region was selected to represent the Lüderitz and Walvis Bay upwelling cells. The boundaries of this domain were at 13 and $15^{\circ} \mathrm{E}, 23$ and $27^{\circ} \mathrm{S}$ (Fig. 1a), representing an ocean area of $56196 \mathrm{~km}^{2}$. This domain covers the continental shelf and a small portion of the continental slope; the mean water depth is $390 \mathrm{~m}$. We selected this domain because it represented an area of the coast where strong upwelling occurs regularly (Demarcq et al., 2007), where this upwelling was spatially distinct from other upwelling cells reported in the literature (Lutjeharms and Meeuwis, 1987; Veitch et al., 2009), and where upwelling was downwind of the station during upwelling events. These criteria were considered desirable because they would provide the best opportunities for relating atmospheric anomalies to upwelling events. These determinations were based on analysis of our SST dataset and HYSPLIT back-trajectories.

Upwelling events were identified based on SST anomalies and $10 \mathrm{~m}$ wind speed anomalies. An event was determined to occur if the average deseasonalized SST of the domain was $0.5^{\circ} \mathrm{C}$ or lower than a smoothed, second-degree polynomial fit to the entire time series and the average $10 \mathrm{~m}$ wind speed of the study area was $2.5 \mathrm{~m} \mathrm{~s}^{-1}$ above a smoothed, seconddegree polynomial fit to the wind data. These thresholds were determined through visual inspection of maps and time series of SST and wind speed data and are specific to the domain chosen, since the data considered were averages of the entire area. One standard deviation of the SST anomaly was $0.92{ }^{\circ} \mathrm{C}$, and 1 standard deviation of the wind speed anomaly was $3.1 \mathrm{~m} \mathrm{~s}^{-1}$. Since the resolution of the SST and wind speed time series was daily, all higher-resolution data falling 

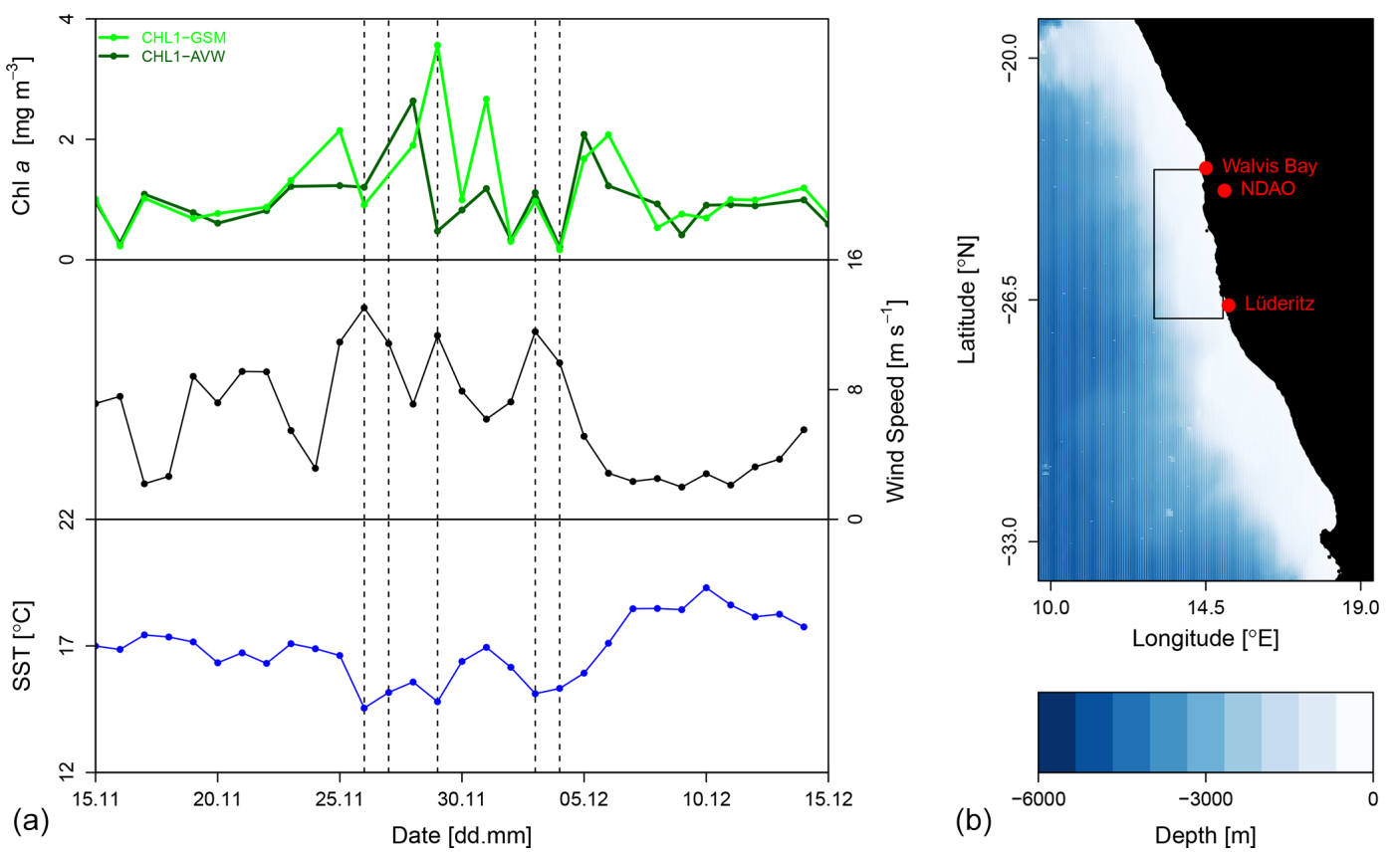

Figure 1. An example of an upwelling event at the end of 2013. The median chlorophyll $a$ of the domain is shown over a period of 1 month, along with the domain-averaged $10 \mathrm{~m}$ wind speed and sea surface temperature (a). Days flagged as upwelling events are shown as dashed vertical lines. The Lüderitz-Walvis Bay domain is shown, overlain on a bathymetric map (b). Data are from Amante and Eakins (2009).

within a day during which an upwelling event occurred were similarly flagged.

Atmospheric anomalies associated with upwelling events were quantified against a baseline determined through a second-harmonic fit that was applied iteratively to all data, excluding all points that lay outside 1 standard deviation from the curve for the subsequent iteration. Small adjustments were made to the anomaly to raise or lower the curve in cases where it did not intersect with background values within $\pm 5 \mathrm{~d}$ of the event. The NDAO data were filtered by wind (wind speeds greater than $2 \mathrm{~m} \mathrm{~s}^{-1}$ and wind direction within the NNW-SSW sector), as well as by back-trajectory to exclude anomalies which were not associated with marine air masses. For the latter, trajectories could not reside for more than $36 \mathrm{~h}$ of the total $120 \mathrm{~h}$ over land and could not travel more than $50 \mathrm{~km}$ inland past NDAO. A final data selection step was to exclude days that had $\mathrm{CO}$ values greater than $15 \mathrm{ppb}$ above the baseline, to remove any time periods that may have been influenced by biomass burning. The filtered time series, with terrestrial influences removed, is shown in Fig. 2.

\subsection{Top-down air-sea flux estimates}

In order to estimate the surface flux associated with atmospheric anomalies due to upwelling events, the approach of Lueker et al. (2003) was adopted. A simple model was employed to describe the change in the concentration of a species within a well-mixed column of air as it moves over a source region (Jacob, 1999):

$\Delta C= \begin{cases}\frac{F}{h q}\left(1-e^{-\frac{q x}{U}}\right), & \text { for } 0 \leq x \leq L, \\ \Delta C_{L}\left(e^{-\frac{q(x-L)}{U}}\right), & \text { for } x \geq L .\end{cases}$

Here $\Delta C$ is the concentration of the species of interest, in mol $\mathrm{m}^{-3}$, expressed as an anomaly against the background. $\Delta C$ is a function of $x$, which is the distance to the observation point from the flux region. $L$ is the point at which the column (with height $h$, in meters) leaves this region, characterized by a constant flux, $F$, in $\mathrm{mol} \mathrm{m}^{-2} \mathrm{~h}^{-1}$, and a constant wind speed, $U$, in $\mathrm{m} \mathrm{h}^{-1}$. After the column leaves the flux region ( $x \geq L$, i.e., when the coast is reached), the loss of $\Delta C$ from its peak at $L\left(\Delta C_{L}\right)$ is governed by dilution due to mixing of background air. This requires the dilution rate constant, $q$, in $\mathrm{h}^{-1}$, to be known.

We solved the equation for $F$ by taking the other variables as follows: $\Delta C$ was determined from our atmospheric record (see Sect. 2.4), wind speeds $(U)$ were obtained from satellite data (Sect. 2.2), and $h$ was taken as the average height of the planetary boundary layer (PBL) for the Lüderitz-Walvis Bay domain over the course of any given event. PBL data were acquired from the European Centre for Medium-Range Weather Forecasting's (ECMWF) ERA-Interim dataset (Dee et al., 1979). $x$ was taken as the length traveled along a backtrajectory from NDAO to the area affected by upwelling.

The dilution rate constant, $q$, was estimated by comparing measurements of $\mathrm{CO}_{2}$ and $\mathrm{CH}_{4}$ made during the $\mathrm{RV}$ Meteor cruise M99 (see Sect. 2.7). Back-trajectories from NDAO 


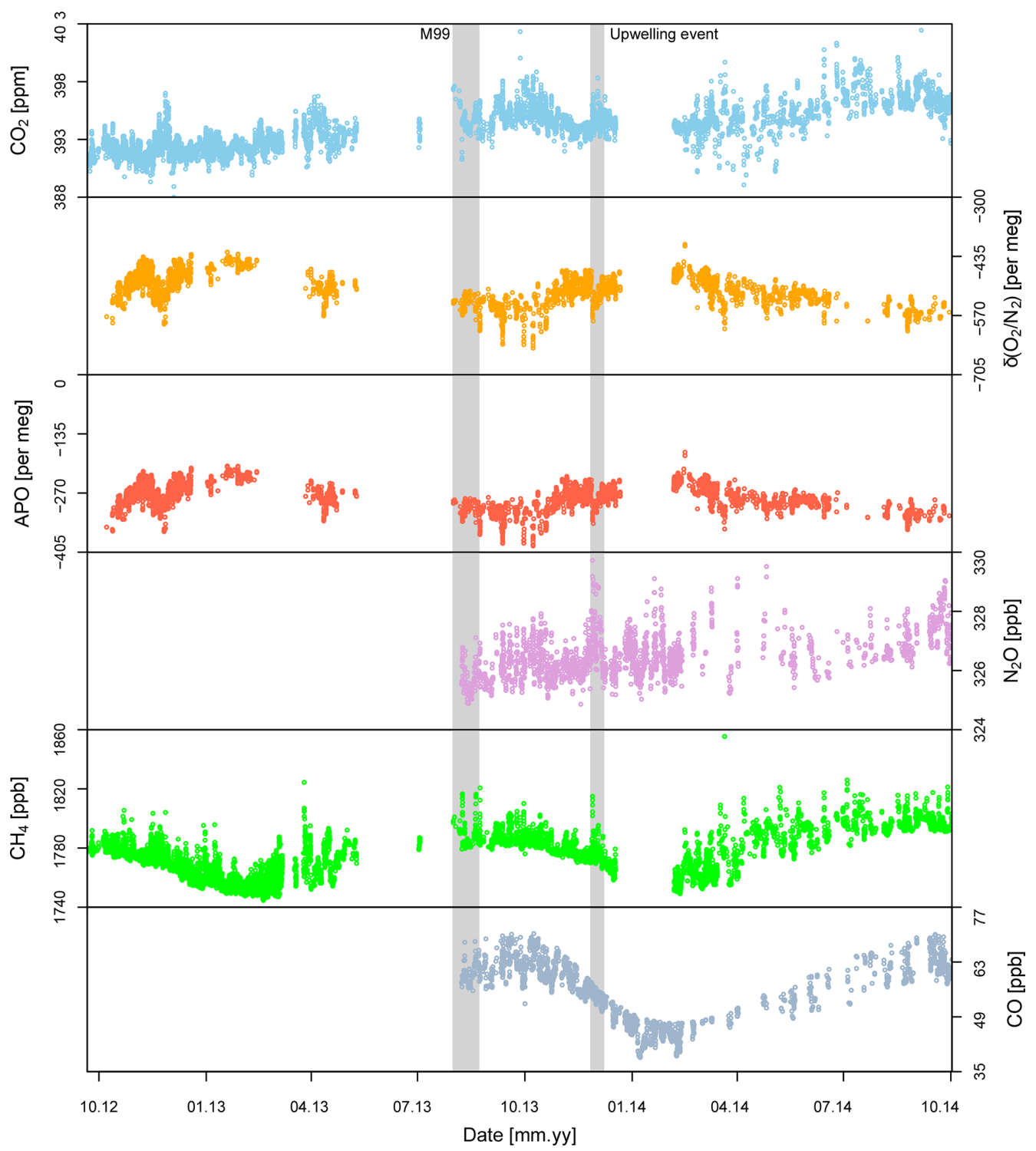

Figure 2. NDAO filtered time series. The NDAO time series, filtered based on back-trajectory and CO. The main measurands of the station are each plotted as 30 min averages. The duration of M99 and the upwelling event discussed in the main text are both demarcated with gray rectangles and denoted with a label. The presence of an upper bound in the $\mathrm{CO}$ data is due to its use as a filtering criterion.

were matched to the closest ship location at the appropriate time. Any back-trajectory points that were within $100 \mathrm{~km}$ of the ship - both horizontally and vertically - within the space of $1 \mathrm{~h}$ were identified, and a dilution rate constant was calculated for both $\mathrm{CO}_{2}$ and $\mathrm{CH}_{4}$, as (Price et al., 2004)

$q=\frac{1}{t} \ln \left(\frac{C_{\mathrm{M} 99}-C_{\mathrm{b}}}{C_{\mathrm{NDAO}}-C_{\mathrm{b}}}\right)$,

where $C_{\mathrm{M} 99}$ and $C_{\mathrm{NDAO}}$ are the mole fractions of $\mathrm{CO}_{2}$ or $\mathrm{CH}_{4}$, as measured in situ on the Meteor or at NDAO, and $C_{\mathrm{b}}$ is taken from the fit to the baseline of the NDAO time series for either species, as described in Sect. 2.4. $t$ is the travel time along the back-trajectory, in hours. While this assumes that there is no flux of the gas between the vessel and the station, we excluded instances when the anomaly was heavily influenced by surface fluxes by filtering for poor agreement between $\mathrm{CO}_{2}$ and $\mathrm{CH}_{4}$. Fluxes of these gases are not well correlated and can go in opposite directions for summertime airsea fluxes, so we assume that it is unlikely that both values of $q$ would be biased by the same amount. From 32 values of $q$ we excluded all but 13 for poor agreement (excluding determinations with $\left.\left|q_{\mathrm{CO}_{2}}-q_{\mathrm{CH}_{4}}\right|>0.01\right)$. The average $( \pm 1 \sigma)$ was taken to arrive at a single value, $0.011 \pm 0.006 \mathrm{~h}^{-1}$. Since this is still a rough approximation, we also present estimates of the estimated flux, $F$, with a value of $q$ tuned to pro- 
vide the best agreement with an in situ flux estimate (see Sect. 2.8).

\subsection{Estimated top-down flux density uncertainty}

Uncertainties were propagated in quadrature, e.g.,

$\sigma_{x}=\sqrt{\sigma_{\mathrm{a}}^{2}+\sigma_{b}^{2}}$,

for operations involving addition or subtraction $(x=a+b)$, and

$\sigma_{x}=\sqrt{\left(\frac{\sigma_{\mathrm{a}}}{a}\right)^{2}+\left(\frac{\sigma_{b}}{b}\right)^{2}} \cdot x$

for operations involving multiplication or division $(x=a b)$, where $\sigma$ is the uncertainty for a given variable. The uncertainty in $\Delta C$ for each species was the propagated analytical uncertainty (see Sect. 2.1) of the difference between the average of $C$ during the maximum of the anomaly and the baseline, plus a small uncertainty term for the value of the baseline itself based on the standard deviation of 1000 simulations in which one-third of data were discarded and the curve fit repeated. $x$ and $L$ were both taken as the standard deviation of the term calculated independently for eight HYSPLIT back-trajectories from NDAO within $0-50 \mathrm{~h}$ back from the anomaly detection. The uncertainty for $U$ was 1 standard deviation of wind speeds for the study domain within the $50 \mathrm{~h}$ period.

\subsection{In situ measurements during RV Meteor cruise M99}

Cruise M99 of the RV Meteor left Walvis Bay on 31 July 2013 and returned to port on 23 August. Continuous or semi-continuous measurements of atmospheric $\mathrm{CO}_{2}$, $\mathrm{N}_{2} \mathrm{O}$, and $\mathrm{CH}_{4}$, as well as dissolved $\mathrm{CO}_{2}, \mathrm{O}_{2}$, and $\mathrm{N}_{2} \mathrm{O}$, were conducted throughout the cruise. Flask samples were taken for discrete measurements of $\delta\left(\mathrm{O}_{2} / \mathrm{N}_{2}\right)$.

Atmospheric measurements of $\mathrm{CO}_{2}$ and $\mathrm{CH}_{4}$ were made with a CRDS analyzer (model G1301, Picarro Inc, Santa Clara, CA, USA) located in the atmospheric chemistry laboratory. The instrument's internal pump was used to draw air through a $7 \mathrm{~m}$ length of $1 / 4^{\prime \prime}$ SERTOflex tubing, at a flow rate of $150 \mathrm{~mL} \mathrm{~min}^{-1}$. Inlets identical to those used at NDAO (Morgan et al., 2015) were placed on the starboard railing of the sixth superstructure deck, just above the atmospheric chemistry lab, at a total height of $\sim 21 \mathrm{~m}$ above sea level. A second-order, instrument-specific water correction was performed in lieu of physical or chemical drying, identical to the method described in Morgan et al. (2015). As the instrument's pressure control seemed to be affected by strong vessel motion, measurements were excluded if the cavity pressure deviated by more than 0.04 torr from the set point of 140 torr. Calibrations were conducted on average every $3 \mathrm{~d}$ and target measurements were made once per day. Reference gases were calibrated at MPI-BGC GASLAB. The uncertainty, derived from the target measurements as at NDAO, was determined to be $\pm 0.03 \mathrm{ppm}$ for $\mathrm{CO}_{2}$ and $\pm 0.43 \mathrm{ppb}$ for $\mathrm{CH}_{4}$. The dataset was filtered for contamination by the ship's exhaust using the relative wind direction data from the ship's meteorological instrumentation.

Flasks for $\delta\left(\mathrm{O}_{2} / \mathrm{N}_{2}\right)$ were taken in triplicate and connected in series downstream of a pump. The pump body and valve plates were aluminum, and the structured diaphragms were made of PTFE. When in use the flow rate $\left(3.2 \mathrm{~L} \mathrm{~min}^{-1}\right)$ was higher than the in situ analyzer flow rates (100-200 $\left.\mathrm{mL} \mathrm{min}^{-1}\right)$. Air was dried with magnesium perchlorate. During sampling, the line was flushed for $5 \mathrm{~min}$ before any air was directed to the flasks, and then a bypass valve was opened and the flasks were flushed for an additional $15 \mathrm{~min}$ before they were sealed again. After closure, the pressure of the flask was about 1.6 bars. Flasks were analyzed with a mass spectrometer at MPI-BGC (Brand, 2005). Storage times were less than 2 months.

Dissolved gas measurements were carried out by means of an autonomous setup for along-track measurements of $\mathrm{CO}_{2}$, $\mathrm{N}_{2} \mathrm{O}$, and $\mathrm{CO}$, which combined the analytical approaches from Pierrot et al. (2009) and Arévalo-Martínez et al. (2013). A full description can be found in Arévalo-Martínez et al. (2019).

The estimated uncertainty of the dissolved $\mathrm{CO}_{2}$ measurements was $\pm 2 \mu \mathrm{atm}$; of dissolved $\mathrm{O}_{2}$ measurements, $\pm 4 \mu \mathrm{mol} \mathrm{L}^{-1}$; of dissolved $\mathrm{N}_{2} \mathrm{O}, \pm 0.1 \mathrm{nmol} \mathrm{L}^{-1}$. The uncertainty of the atmospheric measurements of $\mathrm{N}_{2} \mathrm{O}$ was $\pm 0.9 \mathrm{ppb}$.

\subsection{Shipboard air-sea flux density estimates}

In situ oceanographic and meteorological data were taken from the Meteor's instrumentation. In order to determine the total dissolved inorganic carbon (DIC) content of surface waters, total alkalinity was estimated from temperature, salinity, and dissolved $\mathrm{O}_{2}$ data, using the locally interpolated alkalinity regression (LIAR) version 2 (Carter et al., 2018). The dissociation constants of carbonic acid were also determined from temperature and salinity using the formulations of Millero et al. (2006). The total DIC content was then estimated from the total alkalinity and $f \mathrm{CO}_{2}$. Meteorological data (air temperature, barometric pressure, wind speed, etc.) were observed at a height of $37 \mathrm{~m}$ above sea level. The absolute wind speed measured on the Meteor was converted to $U_{10}$ through the relationship (Justus and Mikhail, 1976)

$$
\begin{aligned}
& U_{10}=U_{\text {meas }}\left(\frac{z_{10}}{z_{\text {meas }}}\right)^{n} \\
& n=\frac{0.37-0.0081 \cdot \ln \left(U_{\text {meas }}\right)}{1-0.0881 \cdot \ln \left(\frac{z_{\text {meas }}}{10}\right)},
\end{aligned}
$$

where $U_{\text {meas }}$ is the wind speed in $\mathrm{m} \mathrm{s}^{-1}$, measured at some height $z_{\text {meas }}$, in meters. 
Marine surface flux densities of $\mathrm{CO}_{2}, \mathrm{O}_{2}$, and $\mathrm{N}_{2} \mathrm{O}$ were estimated for the vessel location throughout M99 from shipboard measurements of atmospheric dry air mole fractions and dissolved aqueous concentrations, according to Eq. (9). While flux densities of $\mathrm{CO}$ were also determined, they are not discussed in this paper as the shipboard-measured flux was too small to be detected as an atmospheric anomaly at NDAO, contrary to what was reported in Morgan (2015). In the case of $\mathrm{O}_{2}$, the atmospheric concentration was measured only sporadically with flask samples, so it was taken as a static value, viz. the mole fraction of $\mathrm{O}_{2}$ in standard dry air, 0.2093 (Aoki et al., 2019). The in situ aqueous solubility of $\mathrm{O}_{2}$ was calculated using the equations of García and Gordon (1992), of $\mathrm{N}_{2} \mathrm{O}$ using those in Weiss and Price (1980), and of $\mathrm{CO}_{2}$ using Weiss (1974). Sea-to-air fluxes (net evasion) are positive.

The flux density ( $F$, in units of $\mathrm{mol} \mathrm{m}^{-2} \mathrm{~s}^{-1}$ ) is typically determined according to Garbe et al. (2014)

$F=k_{\mathrm{w}}\left(C_{\mathrm{w}}-\alpha C_{\mathrm{a}}\right)$,

where $k_{\mathrm{W}}$ is the gas transfer (or piston) velocity, in $\mathrm{m} \mathrm{s}^{-1}, C_{\mathrm{W}}$ is the dissolved concentration in the water phase $\left(\mathrm{mol} \mathrm{m}^{-3}\right)$, and $C_{\mathrm{a}}$ is the concentration of the species in the air in the same units. The formulation can also be altered to accommodate units of partial pressure in both phases. The expression $\alpha C_{\mathrm{a}}$ gives the dissolved concentration in the water phase directly at the surface; $\alpha$ is the Ostwald solubility coefficient: the reciprocal of the dimensionless air-water partition coefficient $\left(K_{\mathrm{AW}}\right)$ for some temperature, $T$, and salinity, $S$ (Mackay and Shiu, 1981).

As there is no definitive $k_{\mathrm{w}}-U_{10}$ parameterization, fluxes were computed with two different parameterizations of $k_{\mathrm{w}}$ : those of Wanninkhof (2014) $\left(k_{\mathrm{W} 14}\right)$ and McGillis et al. (2001) $\left(k_{\mathrm{McG} 01}\right)$ :

$k_{\mathrm{W} 14}=0.251 U_{10}^{2}\left(\frac{S c}{660}\right)^{-0.5}$,

$k_{\mathrm{McG} 01}=\left(3.3+0.026 U_{10}^{3}\right)\left(\frac{S c}{660}\right)^{-0.5}$.

In these equations, $U_{10}$ is the wind speed at $10 \mathrm{~m}$ in height, and $\mathrm{Sc}$ is the Schmidt number of a particular gas at in situ conditions (Jähne et al., 1987; Wanninkhof, 1992). The Schmidt number is dimensionless, and $U_{10}$ is in units of $\mathrm{m} \mathrm{s}^{-1}$, producing $k_{\mathrm{w}}$ in units of $\mathrm{cm} \mathrm{h}^{-1}$. The Schmidt number is scaled to the reference conditions of the parameterization; Schmidt numbers were calculated at in situ conditions by dividing the kinematic viscosity of seawater by the diffusivity of a given gas, using an Eyring-style equation (Eyring, 1936; Jähne et al., 1987):

$D=A \exp \left(\frac{E_{\mathrm{a}}}{R T}\right)$, where $R$ is the ideal gas constant, $T$ is temperature, and $E_{\mathrm{a}}$ is the activation energy for diffusion in water. $A$ and $E_{\mathrm{a}}$ are determined through fits to experimental data. For $\mathrm{O}_{2}$ these were taken from Ferrell and Himmelblau (1967), for $\mathrm{CO}_{2}$ from Jähne et al. (1987), and for $\mathrm{N}_{2} \mathrm{O}$ from Bange et al. (2001). A salinity correction of $4.9 \%$ per 35.5 psu was then applied, this number being the average decrease in diffusivity seen by Jähne et al. (1987) for $\mathrm{He}$ and $\mathrm{H}_{2}$ in an experiment involving artificial seawater. The kinematic viscosity of seawater at in situ conditions was determined by calculating the dynamic viscosity after Laliberté (2007) and the density after Millero and Huang (2009).

\section{Results and discussion}

\subsection{Upwelling events}

Out of $741 \mathrm{~d}, 219 \mathrm{~d}$ met the SST criteria, but only 173 of these met both the SST and WS criteria, representing $23 \%$ of the 2-year study period. From these $173 \mathrm{~d}$ with upwelling events, 102 had atmospheric conditions that allowed for the detection of an anomaly in the atmospheric time series. Of these, 21 events were excluded based on HYSPLIT backtrajectories; the rest were excluded based on local meteorology or elevated CO. This was a conservative approach, since the filtering criteria in part relied on HYSPLIT model results, which could misrepresent the transport pathway and lead to the exclusion of an upwelling event that in fact was favorable for carrying an air mass influenced by upwelling to the station. Despite the greater prevalence of equatorward winds during austral summer, the distribution of events displayed little seasonality (Fig. 3), reflecting the fact that upwelling is a short-term, intraseasonal phenomenon, forced by specific atmospheric conditions (Risien et al., 2004; Goubanova et al., 2013). While upwelling in this area is perennial, seasonality is seen in the intensity of upwelling due to the annual migration of the South Atlantic Anticyclone, with a minimum in austral winter (Hagen et al., 2001; HardmanMountford et al., 2003; Peard, 2007; Veitch et al., 2009; Hutchings et al., 2009).

An example of an upwelling event is given in Figs. 1, 4, and 5. On 27 November 2013, high winds resulted in the creation of a very large pool of colder water on the surface that persisted for $4 \mathrm{~d}$ until winds relaxed and upwelling temporarily ceased on 4 December, when SST dropped again. During these two low SST pulses, Chl $a$ values were higher. A change in the background values of atmospheric potential oxygen (APO), $\mathrm{N}_{2} \mathrm{O}$, and $\mathrm{CH}_{4}$ was seen, with a smaller anomaly for $\mathrm{CO}_{2}$. The largest anomalies for each species came when high winds were from the coastal sector on 28 November.

If the area of high flux was close to the coast, anomalies could arrive within a few hours at NDAO, with the development of the afternoon sea breeze. If the region of flux 


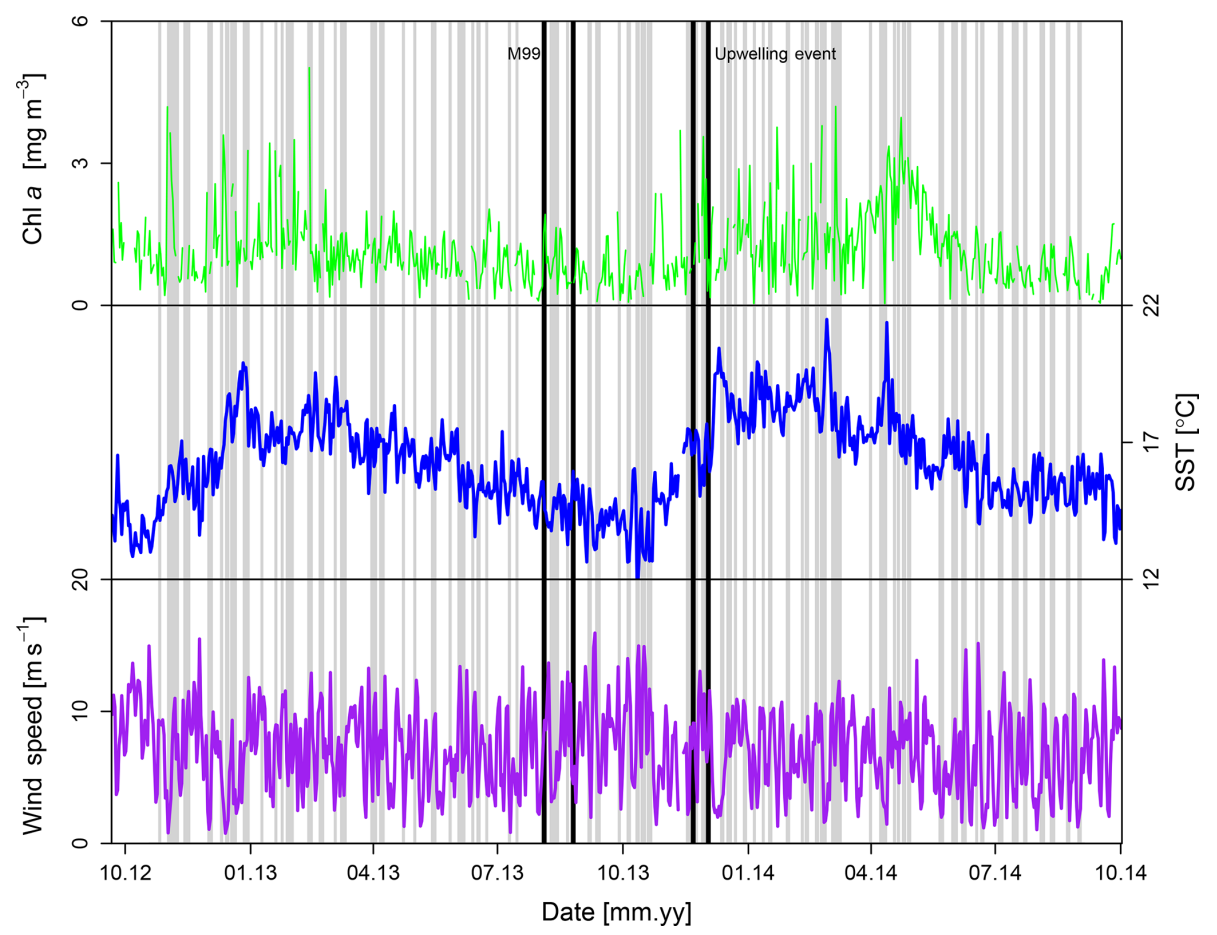

Figure 3. Upwelling events. Surface chlorophyll $a$, temperature, and $10 \mathrm{~m}$ wind speed for the Lüderitz domain over the course of the 2-year study period. Days which have been flagged as containing an upwelling event have been shaded. The duration of M99 and the upwelling event discussed in the main text are both demarcated with black rectangles and denoted with a label.

was closer to Lüderitz, the arrival time could be delayed by as much as $50 \mathrm{~h}$, depending on the wind speed and the degree of meandering of the air mass. Back-trajectories implied that despite the high wind speeds usually seen in this coastal zone, significant travel time ( 1 to $2 \mathrm{~d}$ ) could be expected for most air masses of interest. As a result, the marine surface flux associated with an atmospheric anomaly could only be said to have taken place within $50 \mathrm{~h}$ of its detection. The magnitudes of the average atmospheric anomalies and their corresponding flux density estimates are given in Table 1.

\subsection{Estimated top-down flux densities}

$\mathrm{CO}_{2}$ fluxes were positive for all upwelling events, with an average flux density of $0.70 \pm 0.42 \mu \mathrm{mol} \mathrm{m}^{-2} \mathrm{~s}^{-1}$ and a maximum value of $2.0 \mu \mathrm{mol} \mathrm{m}^{-2} \mathrm{~s}^{-1}$. During upwelling conditions, it is not uncommon to see such strong outgassing of $\mathrm{CO}_{2}$ in a coastal upwelling region; the biological response to new nutrients takes some days to draw down DIC levels (Torres et al., 1999; Loucaides et al., 2012; Cao et al., 2014). Santana-Casiano et al. (2009) used underway systems on cargo ships and weekly wind speeds to arrive at a mean flux between ca. -0.06 and $0.03 \mu \mathrm{mol} \mathrm{m}{ }^{-2} \mathrm{~s}^{-1}$ for the Lüderitz region, with peak rates as high as $0.06 \mu \mathrm{mol} \mathrm{m}^{-2} \mathrm{~s}^{-1}$ in August. González-Dávila et al. (2009) found that the Lüderitz region is undersaturated with respect to $\mathrm{CO}_{2}$, with only upwelled waters seeing oversaturation, with average fluxes on the order of $-0.03 \pm 0.3 \mu \mathrm{mol} \mathrm{m} \mathrm{m}^{-2} \mathrm{~s}^{-1}$. The flux densities for $\mathrm{CO}_{2}$ reported in this study are not necessarily in conflict with these studies, since a yearly averaged flux density is a different quantity from the event-based flux densities. The implication instead is that flux densities attributed to upwelling events are high enough to contribute significantly to the carbon balance of the Lüderitz and Walvis Bay regions.

Typical $\mathrm{O}_{2}$ flux densities were about $-5 \mu \mathrm{mol} \mathrm{m} \mathrm{m}^{-2} \mathrm{~s}^{-1}$. The $\mathrm{O}_{2}$ flux densities inferred from APO are preferred over those calculated with atmospheric $\delta\left(\mathrm{O}_{2} / \mathrm{N}_{2}\right)$, as APO is explicitly formulated to remove land biosphere influences on the relative change in oxygen abundance. A linear regression between the two estimated flux densities yielded a slope of 0.91 and a coefficient of determination of $R^{2}=0.98$. The estimated APO flux density was $11 \%$ lower on average than the $\delta\left(\mathrm{O}_{2} / \mathrm{N}_{2}\right)$-inferred flux density. That the flux densities for $\mathrm{O}_{2}$ calculated with these two formulations are close is a good indication that the atmospheric data were primarily influenced by marine fluxes. These are high flux densities for the marine environment; the estimated average flux density for the entire mid-South Atlantic was $0.03 \mu \mathrm{mol} \mathrm{m}{ }^{-2} \mathrm{~s}^{-1}$ in the inverse modeling study of Gruber et al. (2001) and ca. $0.06 \mu \mathrm{mol} \mathrm{m}^{-2} \mathrm{~s}^{-1}$ in the forward run of a coupled climate and ocean biogeochemistry model of Bopp et al. (2002).

The average flux density attributable to specific upwelling events for $\mathrm{N}_{2} \mathrm{O}$ was $0.66 \pm 0.4 \mathrm{nmol} \mathrm{m}^{-2} \mathrm{~s}^{-1}$, moderate for a 
Table 1. Means of all atmospheric anomalies and top-down flux density estimates for identified upwelling events.

\begin{tabular}{|c|c|c|c|c|c|}
\hline Quantity & $\begin{array}{r}\mathrm{CO}_{2} \\
\left(\mu \mathrm{mol} \mathrm{m}{ }^{-2} \mathrm{~s}^{-1}\right)\end{array}$ & $\begin{array}{r}\delta\left(\mathrm{O}_{2} / \mathrm{N}_{2}\right), \mathrm{O}_{2} \\
\left(\mu \mathrm{mol} \mathrm{m} \mathrm{m}^{-2} \mathrm{~s}^{-1}\right)\end{array}$ & $\begin{array}{r}\mathrm{APO}, \mathrm{O}_{2} \\
\left(\mu \mathrm{mol} \mathrm{m}{ }^{-2} \mathrm{~s}^{-1}\right)\end{array}$ & $\left(\mathrm{nmol} \mathrm{m}^{-2} \mathrm{~s}^{-1}\right)$ & $\begin{array}{r}\mathrm{CH}_{4} \\
\left(\mathrm{nmol} \mathrm{m}^{-2} \mathrm{~s}^{-1}\right)\end{array}$ \\
\hline Mean anomaly $\pm 1 \sigma^{\mathrm{a}}$ & $2.0 \pm 1.1 \mathrm{ppm}$ & $-84 \pm 22$ per meg & $-75 \pm 18$ per meg & $1.9 \pm 0.9 \mathrm{ppb}$ & $14.9 \pm 17 \mathrm{ppb}$ \\
\hline Mean flux density & 0.70 & -6.1 & -5.4 & 0.66 & 5.2 \\
\hline Standard deviation of flux density & 0.42 & 3.0 & 2.6 & 0.52 & 6.7 \\
\hline Mean uncertainty of flux density & 0.43 & 3.8 & 3.3 & 0.41 & 3.2 \\
\hline Mean tuned flux density ${ }^{b}$ & 0.65 & -5.7 & -5.1 & 0.61 & 4.8 \\
\hline Standard deviation of tuned flux density & 0.40 & 2.9 & 2.5 & 0.50 & 6.3 \\
\hline Mean uncertainty of tuned flux density & 0.7 & 6.0 & 5.4 & 0.7 & 5.1 \\
\hline
\end{tabular}

${ }^{\text {a }}$ Flux density units in the column header correspond to all values except for those in this row. ${ }^{\mathrm{b}}$ These flux density values are calculated with the value of $q$ that results in the best agreement between the top-down flux density and shipboard flux density for the M99 event.

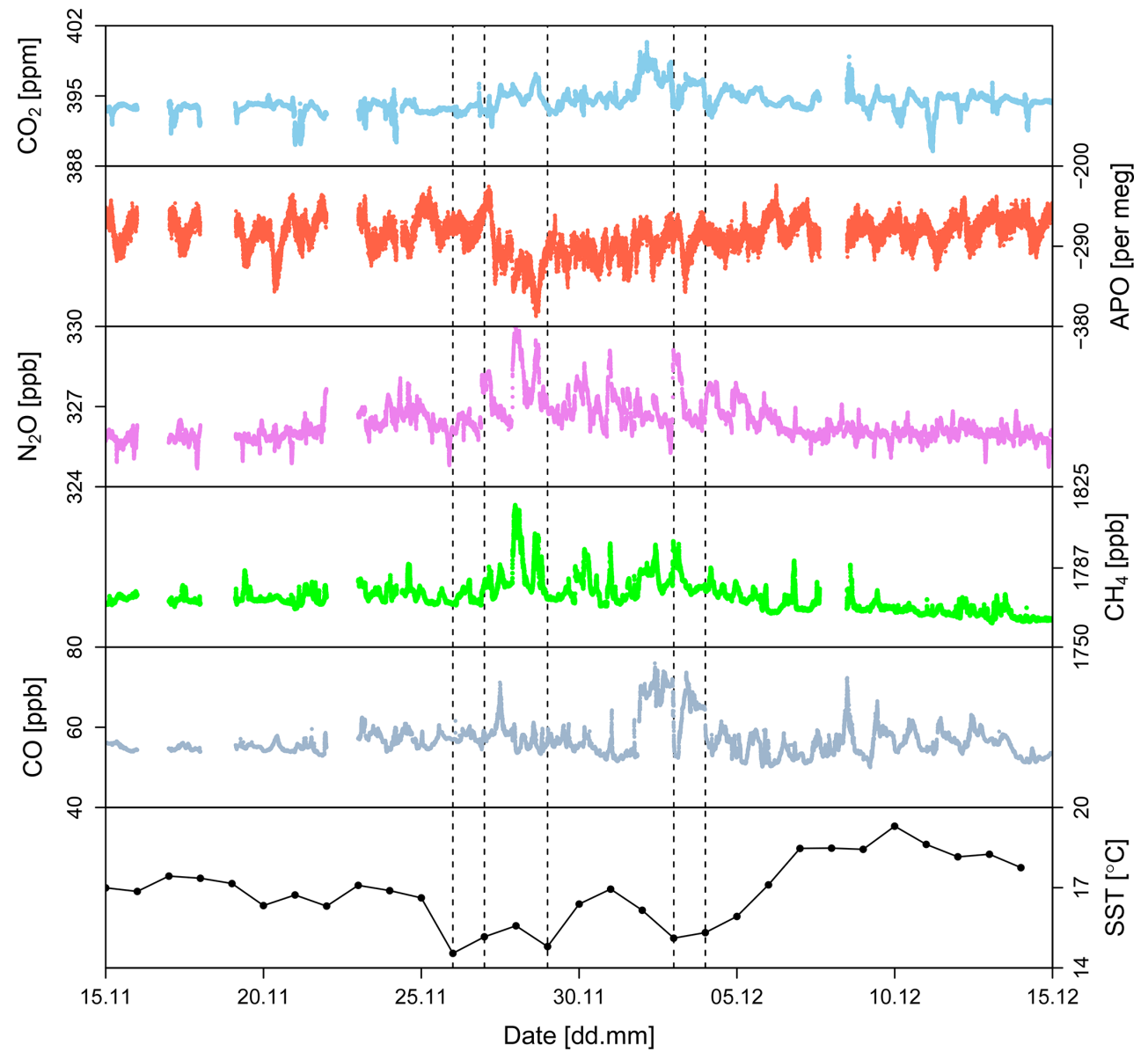

Figure 4. Atmospheric time series at NDAO throughout the upwelling event displayed in Fig. 1. Days flagged as upwelling events are shown as dashed vertical lines.

coastal upwelling system. Flux densities ranged from 0.091$1.3 \mathrm{nmol} \mathrm{m}^{-2} \mathrm{~s}^{-1}$. From surface data taken on cruise 258 of the RV Africana (Emeis et al., 2018) in the Northern Benguela Upwelling System (NBUS) we estimate a maximum flux density of about $0.07-0.5 \mathrm{nmol} \mathrm{m}^{-2} \mathrm{~s}^{-1}$. Frame et al. (2014) observed flux rates as high as $0.52 \mathrm{nmol} \mathrm{m}^{-2} \mathrm{~s}^{-1}$ in the Cape Frio upwelling cell. The 3-D coupled physicalbiogeochemical model of Gutknecht et al. $(2013 \mathrm{a}, \mathrm{b})$ pre- dicts an 8-year mean flux density of $0.02-0.16 \mathrm{nmol} \mathrm{m}^{-2} \mathrm{~s}^{-1}$ for the Walvis Bay region, including both shelf and deeper waters as far west as $10^{\circ} \mathrm{E}$. The mean flux density of the entire M99 cruise was $\sim 0.03 \mathrm{nmol} \mathrm{m} \mathrm{m}^{-2} \mathrm{~s}^{-1}$. The model predicts a maximum flux density at the coast $\left(22-24^{\circ} \mathrm{S}\right)$ of $0.6 \mathrm{nmol} \mathrm{m}^{-2} \mathrm{~s}^{-1}$. Arévalo-Martínez et al. (2019) reported higher $\mathrm{N}_{2} \mathrm{O}$ flux densities from a domain encompassing the latitude range of $16-28.5^{\circ} \mathrm{S}$, ranging between 0.03 and 

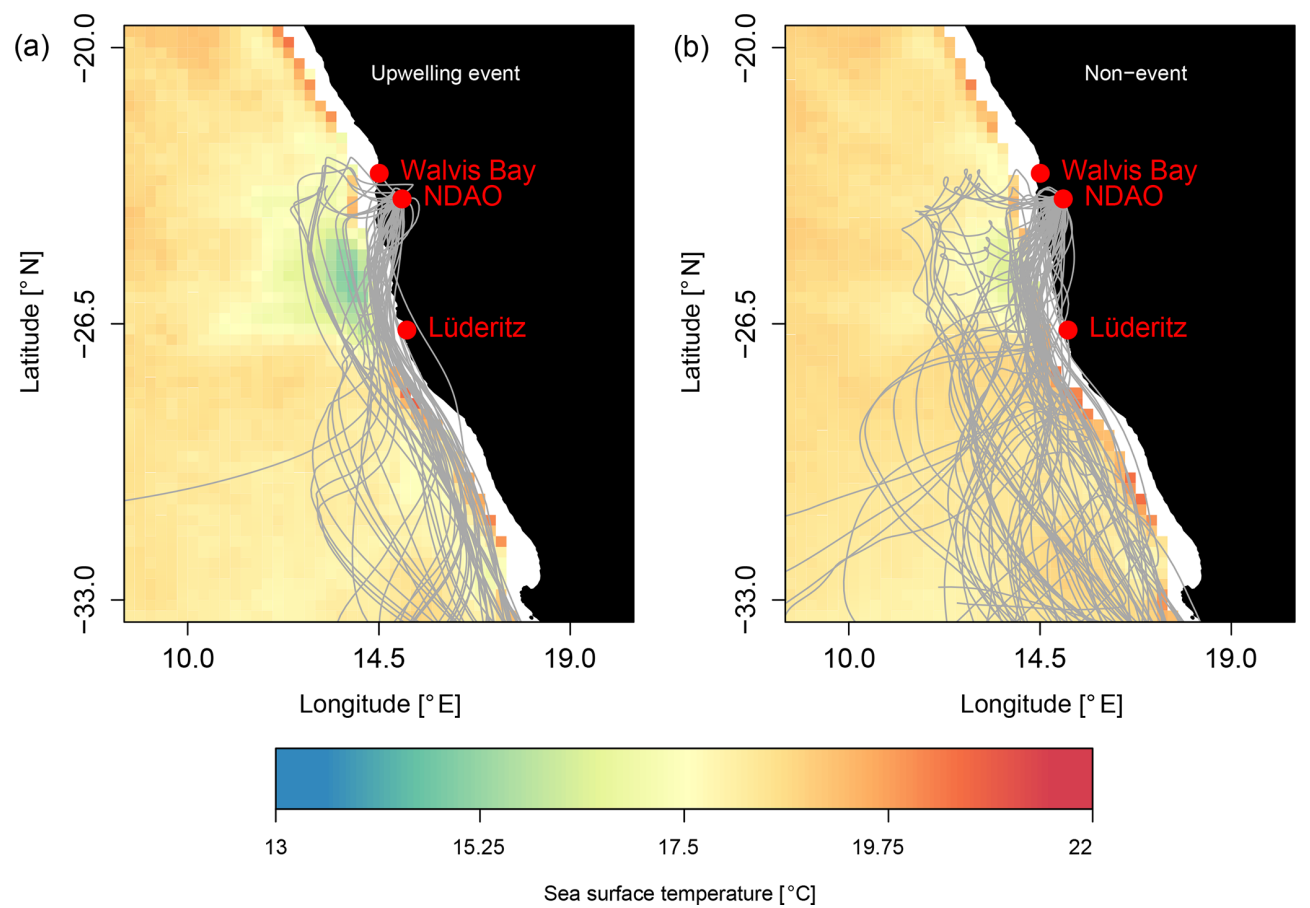

Figure 5. SST during an upwelling event. SST during (a) and preceding and after (b) the upwelling event described in Fig. 2. Five-day back-trajectories calculated for the respective periods are overlain.

$1.67 \mathrm{nmol} \mathrm{m}^{-2} \mathrm{~s}^{-1}$. For the Lüderitz-Walvis Bay area they found values similar to this study: up to $0.20 \mathrm{nmol} \mathrm{m}^{-2} \mathrm{~s}^{-1}$.

The moderate, positive $\mathrm{CH}_{4}$ spikes $(\sim 15 \mathrm{ppb})$ seen during upwelling events corresponded to an average flux density of $5.2 \mathrm{nmol} \pm 3.2 \mathrm{~m}^{-2} \mathrm{~s}^{-1}$ and a maximum of $36.4 \mathrm{nmol} \mathrm{m}^{-2} \mathrm{~s}^{-1}$, a high value even for coastal waters. There are few reported measurements of flux densities or dissolved $\mathrm{CH}_{4}$ for the Benguela region to place these estimates in context. In what are likely the first measurements of dissolved methane in the Benguela, Scranton and Farrington (1977) observed concentrations near Walvis Bay at multiple depths in the $200-900 \mathrm{nM}$ range. The only other available data known to the authors are from cruise 258 of the RV Africana in 2009. These measurements were taken at a variety of depths (up to $400 \mathrm{~m}$ ) and ranged from 4.7 to $140.0 \mathrm{nM}$. Using the nine samples taken from the top $15 \mathrm{~m}$ from this cruise, at in situ conditions, a flux of $0.08-1.5 \mathrm{nmol} \mathrm{m}^{-2} \mathrm{~s}^{-1}$ would be expected, from dissolved concentrations ranging from 6.0 to $140 \mathrm{nM}$. Naqvi et al. (2010) used the data from Scranton and Farrington (1977) and from Monteiro et al. (2006) to estimate flux densities of $0.03-8.7 \mathrm{nmol} \mathrm{m}^{-2} \mathrm{~s}^{-1}$, the upper end-member of which compares favorably with the rates found in this study for the same ocean region. Though the latter study observed concentrations at a mooring near Walvis Bay as high as $10 \mu \mathrm{M}$, these data were from an uncalibrated probe and are not usable for a direct comparison to other campaigns. In other EBUS, reported flux densities are much lower.

\subsection{M99: atmospheric measurements}

Only $\mathrm{CO}_{2}$ and $\mathrm{CH}_{4}$ were measured continuously in the atmosphere on M99. During the first days of the cruise, before the main upwelling event, a synoptic event brought elevated mixing ratios of $\mathrm{CO}_{2}$ and $\mathrm{CH}_{4}$ offshore (Fig. 6). The shipboard measurements of $\mathrm{CO}_{2}$ showed sporadic enhancements relative to the smoothed station background. These enhancements coincided with the regions of higher flux closer to the coast encountered under upwelling conditions (Figs. 6 and 7). In contrast, apart from the initial synoptic event, $\mathrm{CH}_{4}$ was consistently at background levels, usually below the value seen at NDAO. The variability of both species is higher at NDAO than on the Meteor primarily because NDAO has a strong local wind system which causes diurnal variability in $\mathrm{CO}_{2}$ and $\mathrm{CH}_{4}$, as air from the interior is contrasted with marine air brought to the station by the daily sea breeze (Morgan, 2015).

\subsection{M99: dissolved gas concentrations}

All three species measured underway in the water phase showed the largest deviation from atmospheric equilibrium closest to shore (Fig. 7). $f \mathrm{CO}_{2}$ ranged from 355.5 to $852.3 \mu \mathrm{atm}$ ( $87.8 \%$ to $207.3 \%$ saturation), with most of the observed oversaturation occurring under upwelling conditions. Dissolved oxygen was mostly at saturation or slightly above, although close to shore the concentration dropped to a minimum of $180.8 \mu \mathrm{M}$ (67\% saturation). $\mathrm{N}_{2} \mathrm{O}$ surface 
concentrations were rather low for an upwelling region, but agreed well with previously reported values, with the maximum observed concentration of $20.5 \mathrm{nM}$ being comparable to the highest values seen by Frame et al. (2014) for surface measurements in the same region. Recently, ArévaloMartínez et al. (2019) reported surface $\mathrm{N}_{2} \mathrm{O}$ concentrations ranging between 8 and $31 \mathrm{nM}$ for the northern Benguela region. Besides this, the only other in situ measurements of $\mathrm{N}_{2} \mathrm{O}$ in the Benguela region known to the authors are in the Marine Methane and Nitrous Oxide (MEMENTO; https: //memento.geomar.de/de, last access: 28 July 2015) database (Bange et al., 2009; Kock and Bange, 2015), from cruise 258 in 2009 of the RV Africana. In this dataset, dissolved $\mathrm{N}_{2} \mathrm{O}$ concentrations for surface waters (the top $15 \mathrm{~m}$ ) were in the range of 5-51 nM, which brackets the range measured during M99.

The main upwelling event of the cruise, in the LüderitzWalvis Bay cell, began on 4 August 2013 and lasted until 11 August (Fig. 8). Wind speeds declined rapidly after $8 \mathrm{Au}$ gust. The upwelling event was encountered by the Meteor starting on 8 August, as the vessel reached an upwelling filament, the outer edge of which was subject to net evasion of all three gases $\left(\mathrm{CO}_{2}, \mathrm{O}_{2}, \mathrm{~N}_{2} \mathrm{O}\right)$, likely a result of warming temperatures that would reduce their solubility. The positive flux ratio of $\mathrm{O}_{2}: \mathrm{CO}_{2}$ is generally only produced when thermal processes dominate the air-sea flux.

\subsection{Comparison of top-down and bottom-up flux density estimates}

Due to local wind variability, suitable conditions for detecting the upwelling event encountered by the Meteor were only seen at NDAO on 6, 8, and 10 August 2013. As the vessel was not always in the upwelling cell, only a single atmospheric anomaly at NDAO could be matched to in situ shipboard measurements, namely an anomaly occurring on 10 August. The highest flux rates (positive for $\mathrm{CO}_{2}$ and $\mathrm{N}_{2} \mathrm{O}$, and negative for $\mathrm{O}_{2}$ ) were seen within the recently upwelled waters experiencing high wind speeds. Fluxes displayed coupling between all three species, though the area of high flux density for $\mathrm{O}_{2}$ and $\mathrm{N}_{2} \mathrm{O}$ was more sharply defined than for $\mathrm{CO}_{2}$.

The top-down estimates agreed reasonably well with the corresponding mean shipboard estimates for a selected $7.5 \mathrm{~h}$ period that coincided with the largest flux densities (Fig. 8 and Table 2), but overestimates the flux density relative to the mean shipboard estimate for the flux event. Agreement was best for $\mathrm{CO}_{2}$, but was as poor as a factor of 3 for $\mathrm{N}_{2} \mathrm{O}$, though given the simplicity of the top-down estimate, this seems fairly reasonable.

The choice of gas transfer velocity parameterization $\left(k_{\mathrm{w}}\right)$ was significant in determining the magnitude of the agreement, and the degree of this correspondence between the topdown and shipboard gas transfer velocity-specific estimates varied between species. The cubic relationship of $k_{\mathrm{McG} 01}$ produced higher fluxes during the M99 event and was in better agreement with the top-down estimate. While this provides a measure of confidence in the top-down flux density estimates, it should be noted that neither of the estimated uncertainties for the top-down or bottom-up approaches accounts for errors incurred by the simplifying assumptions within their formulations, and these comparisons should not be considered a "calibration" of the flux determination or $k_{\mathrm{w}}$ parameterization. We suspect that our top-down estimates are overestimates. Cubic relationships with wind speed, derived mostly from eddy covariance data, have not been disproved per se, but after reevaluation of field data (Landwehr et al., 2014), the weight of evidence seems to favor a quadratic relationship (Roobaert et al., 2018), and hence we prefer $k_{\mathrm{W} 14}$ for comparison.

\subsection{Model uncertainty and limitations}

The model makes many simplifying assumptions, which we have attempted to incorporate into our uncertainty assumptions. The assumption of a constant boundary layer height, $h$, is of course not realistic, but we have attempted to account for natural variations in this parameter with our uncertainty range. The uncertainty in the distance traveled depends on the accuracy of the back-trajectories, although major errors in transport (e.g., a continental air mass causing the anomaly) are likely to be excluded due to the filtering criteria of the atmospheric record. We also note that the model is sensitive to the dilution rate constant, $q$, and that this is the parameter we know least well. Previous studies suggest that our in situ determination is reasonable; Price et al. (2004) used multiple species and a model approach to arrive at a mean $q$ of $0.010 \pm 0.004 \mathrm{~h}^{-1}$, which is nearly identical to our value of $0.011 \pm 0.006 \mathrm{~h}^{-1}$, although the spatial and temporal scale they considered was larger. Dillon et al. (2002) observed rates that were higher for a Sacramento pollution plume, ca. $0.2 \mathrm{~h}^{-1}$.

While we cannot determine for specific events when the simplifying assumptions of the model are problematic, we assume that variations in the dilution rate, the boundary layer height, and errors in transport generally average out and that the estimated average flux from upwelling events is representative. If we "tune" the model by finding the value of $q$ which results in the value of $F$ that best matches the M99 event to the $k_{\mathrm{W} 14}$ fluxes for each species, we get a lower value of $0.0058 \pm 0.007 \mathrm{~h}^{-1}$. Using this value of $q$, we obtain the tuned fluxes reported in Table 2. Though these fluxes have a higher uncertainty associated with them, due to the higher uncertainty in $q$, we recommend these values, as the top-down and bottom-up comparison suggests that the model overestimates the fluxes. 


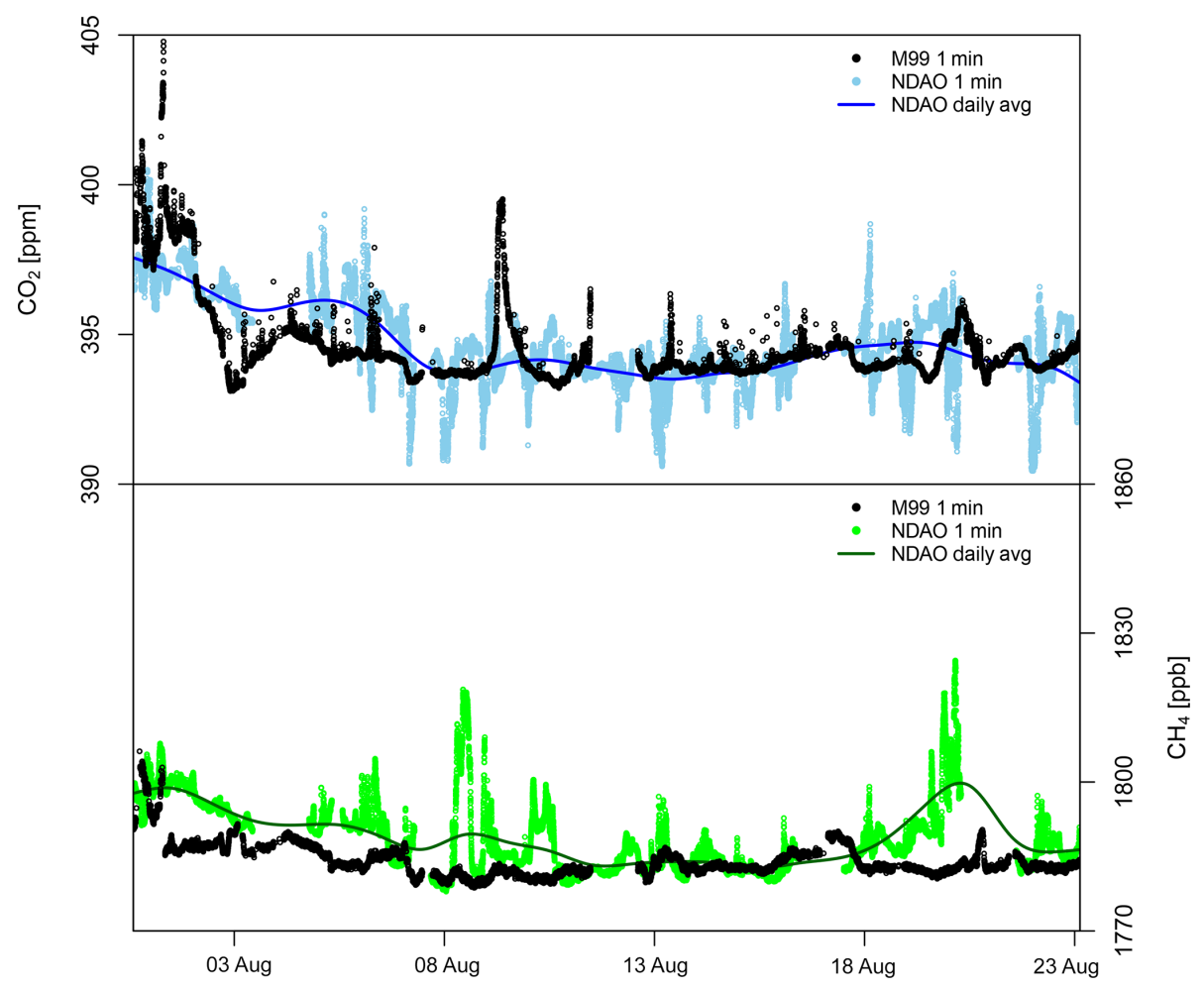

Figure 6. Time series of atmospheric $\mathrm{CO}_{2}$ and $\mathrm{CH}_{4}$ during M99. Atmospheric observations of $\mathrm{CO}_{2}$ and $\mathrm{CH}_{4}$ during the $\mathrm{M} 99$ cruise. $\mathrm{Black}$ points are the shipboard measurements and colored points are the NDAO measurements. Also shown for both species is a smooth fit to a rolling daily average. The diurnal variability was caused by a sea breeze-land breeze dynamic, with lower $\mathrm{CO}_{2}$ mole fractions and higher $\mathrm{CH}_{4}$ mole fractions occurring at night during the land breeze.

Table 2. Comparisons of top-down and underway flux density estimates for the M99 upwelling event (9 August 2013)

\begin{tabular}{llrrr}
\hline Species & Unit & Top-down & Shipboard $\left(k_{\mathrm{W} 14}\right)$ & Shipboard $\left(k_{\mathrm{McG}}\right)$ \\
\hline $\mathrm{CO}_{2}$ & $\mu \mathrm{mol} \mathrm{m}{ }^{-2} \mathrm{~s}^{-1}$ & $0.52 \pm 0.3$ & $0.45 \pm 0.2$ & $0.67 \pm 0.2$ \\
$\delta\left(\mathrm{O}_{2} / \mathrm{N}_{2}\right), \mathrm{O}_{2}$ & $\mu \mathrm{mol} \mathrm{m}{ }^{-2} \mathrm{~s}^{-1}$ & $-3.4 \pm 2$ & $-1.6 \pm 0.5$ & $-2.3 \pm 0.7$ \\
$\mathrm{APO}, \mathrm{O}_{2}$ & $\mu \mathrm{mol} \mathrm{m}^{-2} \mathrm{~s}^{-1}$ & $-2.8 \pm 2$ & $-1.6 \pm 0.5$ & $-2.3 \pm 0.7$ \\
$\mathrm{~N}_{2} \mathrm{O}$ & nmol m$^{-2} \mathrm{~s}^{-1}$ & $0.42 \pm 0.2$ & $0.15 \pm 0.08$ & $0.22 \pm 0.1$ \\
\hline
\end{tabular}

\subsection{Stoichiometry}

Correlation slopes of atmospheric species can provide further confidence and insight into source processes if there is an underlying biogeochemical relationship. The well-known inverse relationship between $\mathrm{N}_{2} \mathrm{O}$ and $\mathrm{O}_{2}$ in the ocean, for instance, is a result of organic matter decomposition and nitrification (Cohen and Gordon, 1979; Nevison et al., 2003; Naqvi et al., 2010; Frame et al., 2014). The tight coupling between $\mathrm{N}_{2} \mathrm{O}$ and $\mathrm{O}_{2}$ seen in surface concentrations during M99 is preserved during air-sea gas exchange, as these gases behave similarly (Fig. 9). The observed linear correlation in surface waters between these two species is also an indication that intense denitrification was not occurring in the $\mathrm{OMZ}$ at the time of sampling, which, if it were taking place, would lead to a breakdown in this relationship at low $\mathrm{O}_{2}$ (Cohen and Gordon, 1979). The approximate molar ratio of these two species, $-0.8 \times 10^{-4}$ to $-1 \times 10^{-4}\left(\mathrm{~N}_{2} \mathrm{O}: \mathrm{O}_{2} ; \mathrm{mol} \mathrm{mol}^{-1}\right)$, is the same observed by Lueker et al. (2003) for the Trinidad Head region and appears to be a globally consistent value (Nevison et al., 2005; Manizza et al., 2012).

This linear regression slope is often expressed in terms of the excess $\mathrm{N}_{2} \mathrm{O}$ (measured $\mathrm{N}_{2} \mathrm{O}$ minus $\mathrm{N}_{2} \mathrm{O}$ at saturation) and apparent oxygen utilization (saturation minus observed), $\Delta \mathrm{N}_{2} \mathrm{O}-\mathrm{AOU}$ in $\mathrm{nmol} \mu \mathrm{mol}^{-1}$. Quantified in this way, it has been used as an estimate of the yield of $\mathrm{N}_{2} \mathrm{O}$ as a function of the amount of oxygen consumed (Nevison et al., 2003). However, the relationship is not strictly linear, since $\mathrm{N}_{2} \mathrm{O}$ production is enhanced at low oxygen levels (Nevison et al., 2003; Naqvi et al., 2010; Trimmer et al., 2016). $\Delta \mathrm{N}_{2} \mathrm{O}-\mathrm{AOU}$ is also sensitive to mixing, as $\mathrm{N}_{2} \mathrm{O}$ production rates vary widely in the ocean, meaning that the mix- 

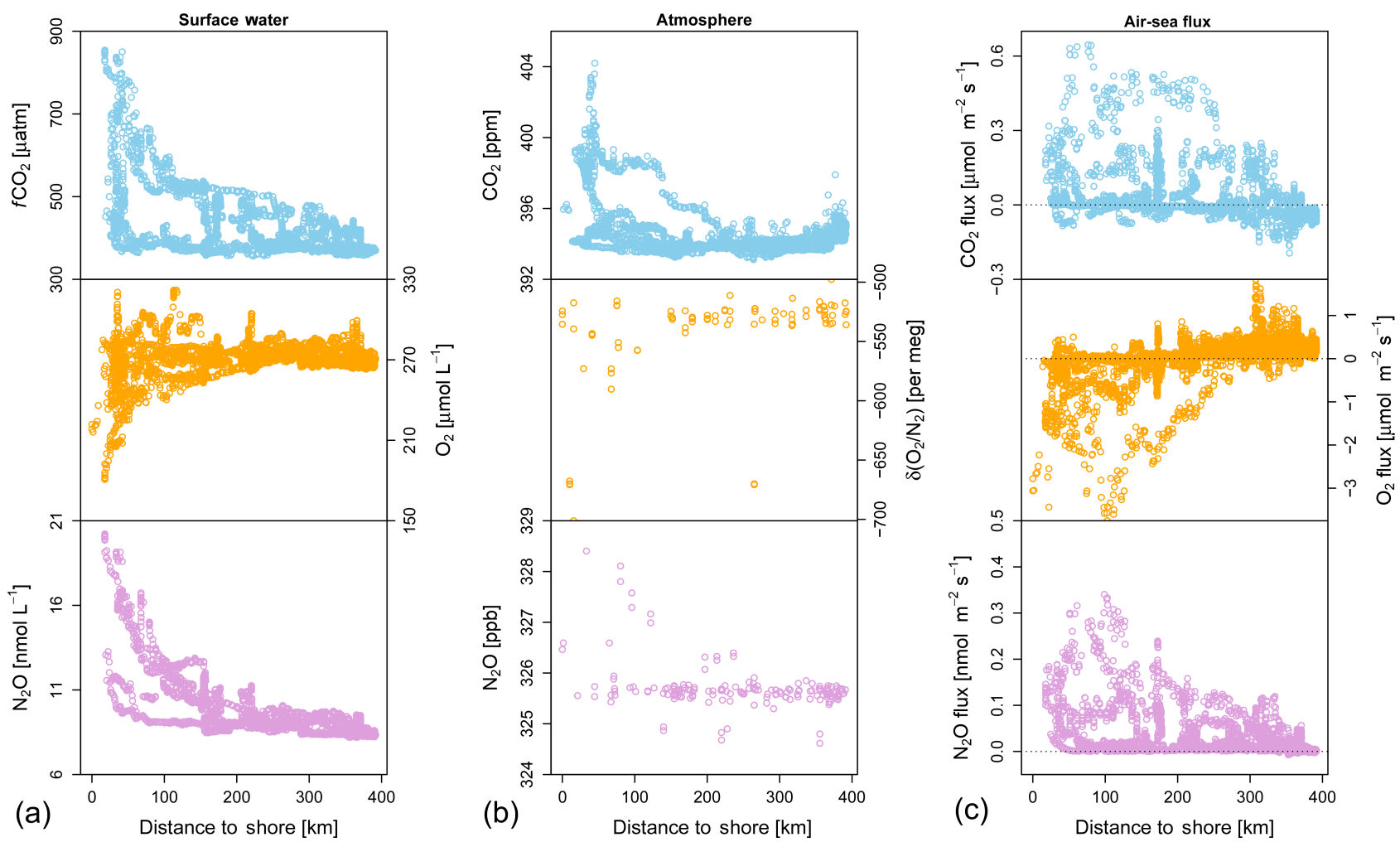

Figure 7. Underway measurements of air-sea fluxes and dissolved concentrations during M99. Dissolved concentrations of $\mathrm{CO}_{2}, \mathrm{O}_{2}$, and $\mathrm{N}_{2} \mathrm{O}$ in surface water, at ca. $6 \mathrm{~m}$ depth during M99 (a), the atmospheric abundance of all three species (b), and air-sea flux densities for $\mathrm{CO}_{2}$, $\mathrm{O}_{2}$, and $\mathrm{N}_{2} \mathrm{O}$ with $k_{\mathrm{W} 14}(\mathbf{c})$, all as a function of distance from shore. The dashed line in the rightmost panels indicates equilibrium between seawater and the atmosphere (i.e., no flux).

ing of water masses with different compositions can overwhelm the in situ production signal (Suntharalingam and Sarmiento, 2000; Nevison et al., 2003). The $\Delta \mathrm{N}_{2} \mathrm{O}-\mathrm{AOU}$ for M99 was $0.088 \pm 0.003 \mathrm{nmol}_{\mu \mathrm{mol}^{-1}}$, with an intercept of $1.6 \pm 0.04 \mathrm{nmol}$ and an $R^{2}$ of 0.69 . This is a low value, nearly identical to results from the eastern basin of the subtropical North Atlantic, where South Atlantic Central Water is found (Cohen and Gordon, 1979; Suntharalingam and Sarmiento, 2000; Walter et al., 2006), and the eastern equatorial Atlantic (Arévalo-Martínez et al., 2017). Frame et al. (2014) showed that most of the $\mathrm{N}_{2} \mathrm{O}$ in the Benguela Current region is produced in the water column and in the sediment by nitrifier denitrification (Frame et al., 2014). Nevertheless, a substantial portion of this $\mathrm{N}_{2} \mathrm{O}$ remains at depth (with a concentration maximum at $200-400 \mathrm{~m}$ ) and is advected away from the region, without the chance of atmospheric release (Gutknecht et al., 2013b, a; Frame et al., 2014). Hence, the low $\Delta \mathrm{N}_{2} \mathrm{O}-\mathrm{AOU}$ value found for the Meteor cruise probably reflects both physical and biogeochemical dynamics.

In the case of variations of $\mathrm{O}_{2}$ and $\mathrm{CO}_{2}$, the stoichiometry of surface waters is not preserved after air-sea exchange, as the majority of carbon is speciated in the carbonate system, and only the portion that remains as dissolved $\mathrm{CO}_{2}$ is available for air-sea gas exchange. This leads to a change in the ratio, for instance, from $0.58 \pm 0.03$ in surface waters to $-6.53 \pm 0.42$ in the atmosphere, for the upwelling event encountered during RV Meteor cruise M99 (Fig. 8). These two species can become decoupled through the influences of changing solubility, which would drive evasion of both gases, and net biological production, which would drive evasion of $\mathrm{O}_{2}$ and invasion of $\mathrm{CO}_{2}$. These complicating influences are the likely reason for the poorer correlation seen between these two species when compared with $\mathrm{N}_{2} \mathrm{O}$ and $\mathrm{O}_{2}$.

While the top-down flux density estimates cannot be confirmed with shipboard estimates of flux densities for $\mathrm{CH}_{4}$, it is worth considering that concentrations of methane in bottom waters on the Namibian shelf are likely the highest ever measured in an open coastal system. Values as high as $475 \mu \mathrm{M}$ in the bottom waters and greater than $5000 \mu \mathrm{M}$ in sediment porewaters have been observed (Scranton and Farrington, 1977; Monteiro et al., 2006; Brüchert et al., 2009; Naqvi et al., 2010). In the water column, the concentration maximum is usually at the seabed or in bottom water, but it is variable and can even occur at $1 \mathrm{~m}$ depth (Brüchert et al., 2009). Dissolved methane concentrations are tightly coupled with $\mathrm{O}_{2}$ and show considerable variability, with elevated concentrations being triggered by episodes of hypoxia (Monteiro et al., 2006; Brüchert et al., 2009). The pulse-like nature of 

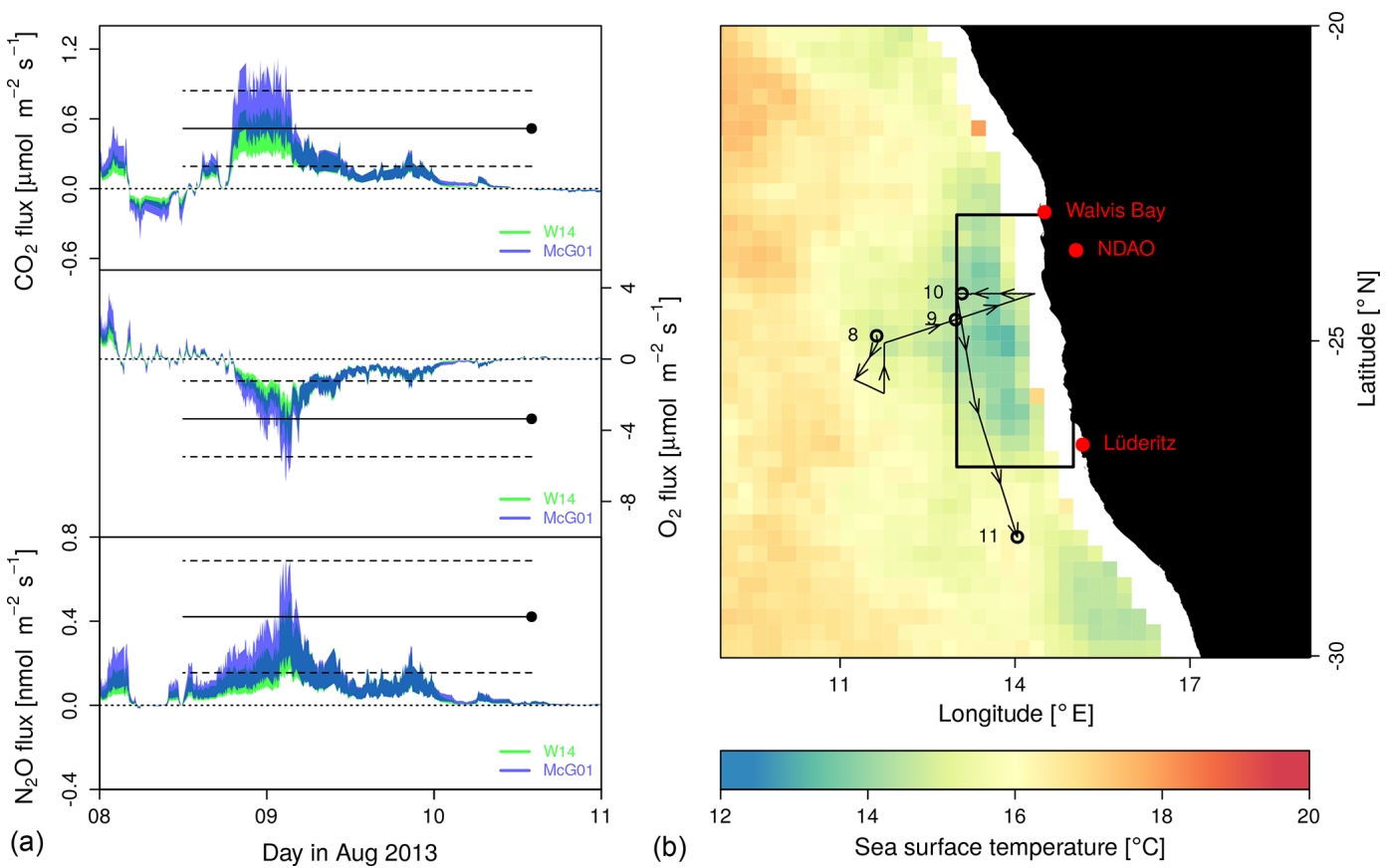

Figure 8. Air-sea flux densities for $\mathrm{CO}_{2}, \mathrm{O}_{2}$, and $\mathrm{N}_{2} \mathrm{O}$ using bottom-up methods (a), with a shaded envelope depicting the estimated surface flux and its uncertainty. Two estimates are shown, each made with a different parameterization for $k_{\mathrm{w}}$. A positive value indicates net evasion. W14 and McG01 refer to the specific gas transfer velocity parameterization used. The top-down flux density estimate is plotted as a dot at the time of the peak of the associated atmospheric anomaly. The horizontal line extending from each dot represents the time period during which the flux density associated with the anomaly was estimated to have occurred. Dotted lines indicate the uncertainty of the top-down estimate. Grid-cell average TRMM SST data for the $3 \mathrm{~d}$ period are overlain with a cruise track and the Lüderitz-Walvis Bay domain (b). The days in August 2013 are marked with labels and open circles on the cruise track.

$\mathrm{CH}_{4}$ in the Benguela region means that the full range of dynamics cannot be captured with a campaign-based sampling approach (Brüchert et al., 2009). What is clear is that there is a tremendous amount of methane production at depth but that the source is variable in strength (Emeis et al., 2004; Brüchert et al., 2009). Considering the facts that large pockets of free methane gas are contained in the sediment in the Walvis Bay region, craters and pockmarks are known to exist on the seafloor, and bubble streams have been observed coming from the seabed, it seems that there is a possible mechanism by which methane produced in sediments can be abruptly transported to the surface and, hence, avoid oxidation (Emeis et al., 2004; Brüchert et al., 2006, 2009). Consequently, the Benguela Current is a suspected source of $\mathrm{CH}_{4}$ to the atmosphere, but the amount is ill constrained (Naqvi et al., 2010); Emeis et al. (2018) recently estimated the total annual emission for the entire system to be less than $0.17 \mathrm{Tg}$ $\mathrm{CH}_{4} \mathrm{yr}^{-1}$.

Interestingly, methane was not well correlated with either $\mathrm{APO}$ or $\mathrm{CO}_{2}$ in the atmosphere during all upwelling events, suggesting a spatial decoupling (since a cross-correlation analysis indicated this was not a result of lag/temporal decoupling) between methane and these two species. While background observations of $\mathrm{CH}_{4}$ were generally well correlated with $\mathrm{CO}_{2}$ and $\mathrm{O}_{2}$ at NDAO, only some upwelling events showed such coupling; it seems there is a general relationship between methane and oxygen, but it is not consistent and is occasionally non-existent. Unfortunately, since there are still very few measurements of water-column $\mathrm{CH}_{4}$ in the Benguela, a full explanation of the methane source remains elusive. From these atmospheric trends it can only be deduced that there is some separate biogeochemical influence on methane that is not exerted over $\mathrm{CO}_{2}, \mathrm{O}_{2}$, or $\mathrm{N}_{2} \mathrm{O}$. This observation is arguably consistent with the concept of a dominant sedimentary source of methane that is more localized within the inshore mud belt, where high POC fluxes have created a thick layer of diatomaceous ooze containing free methane gas pockets (Emeis et al., 2004; Brüchert et al., 2006, 2009; van der Plas et al., 2007).

\subsection{Regional flux context and future steps}

To put our estimated flux densities into the context of regional greenhouse gas budgets, it is necessary to have an approximation of the area involved. For the sake of discussion only, we can very roughly estimate the total annual flux of each species from the Walvis Bay-Lüderitz domain by assuming that grid cells with wind speeds above $3.5 \mathrm{~m} \mathrm{~s}^{-1}$ and a deseasonalized SST below $-0.1{ }^{\circ} \mathrm{C}$ were grid cells with upwelling, that upwelling extends to the coast, and that 

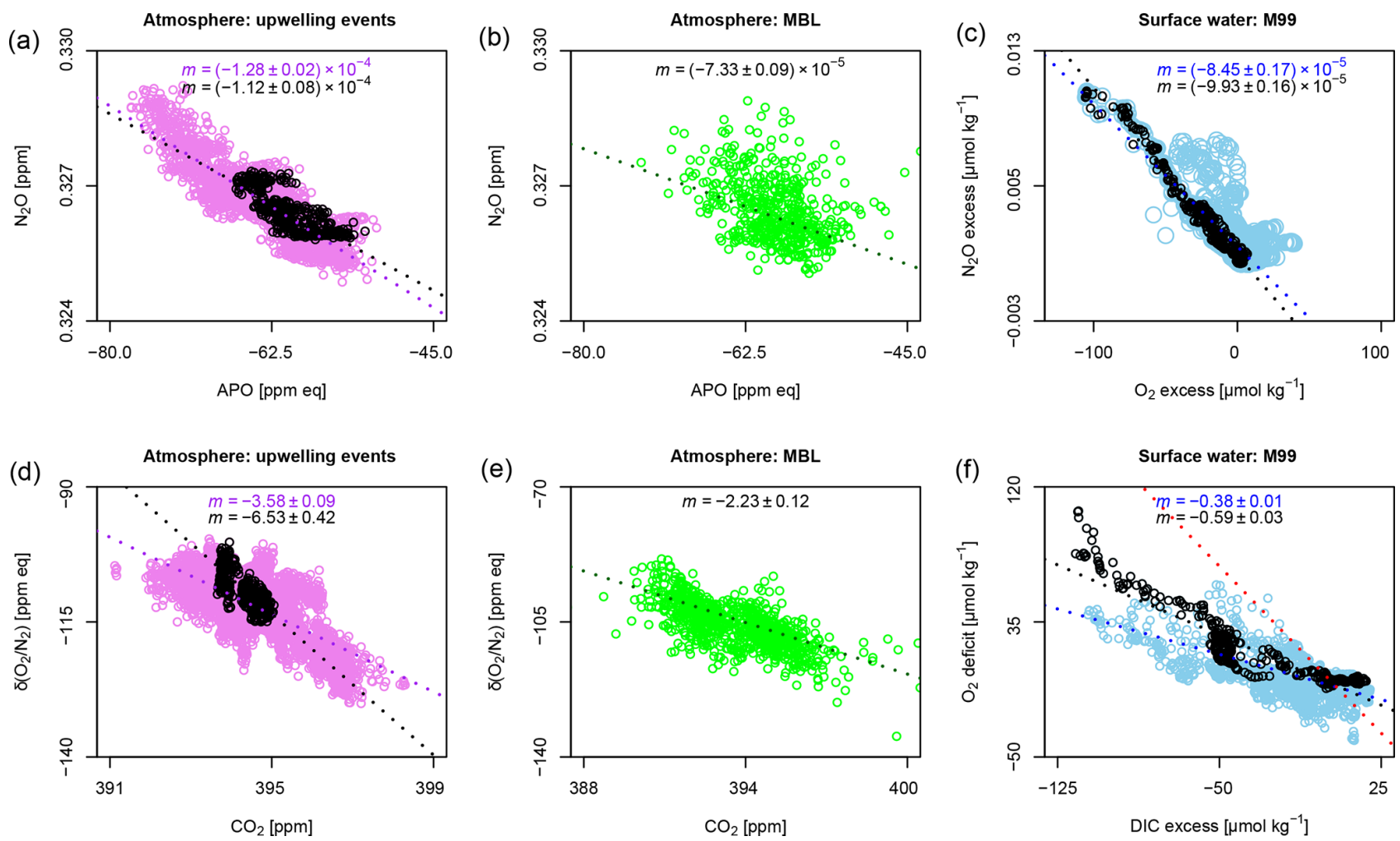

Figure 9. $\mathrm{N}_{2} \mathrm{O}$ and $\mathrm{O}_{2}$ variability in the atmosphere and surface water. Comparison of the variability of $\mathrm{O}_{2}$ with respect to $\mathrm{N}_{2} \mathrm{O}$ and $\mathrm{CO}_{2}$ with respect to $\mathrm{O}_{2}$ at NDAO and in surface water. Displayed are the data corresponding to atmospheric anomalies associated with upwelling events (a), of all marine boundary layer air masses as selected by back-trajectories (center), and dissolved concentrations of $\mathrm{CO}_{2}, \mathrm{~N}_{2} \mathrm{O}$, and $\mathrm{O}_{2}$ during M99 (b). Atmospheric $\mathrm{O}_{2}$ is expressed as APO in ppm equivalents, and dissolved concentrations are expressed as the difference between the measured concentration and the concentration at saturation, i.e., an excess, except for (f), where it is shown as a deficit. In that plot, the Redfield ratio of 1.45 is plotted as a dotted red line for reference. Slopes $(m)$ are given at the top of each plot. The black circles correspond to the upwelling event encountered during M99 (see Fig. 8).

each grid cell with upwelling had the same flux density, i.e., the top-down estimated flux density for a given upwelling event. This approach is very crude and would result in an underestimate, since transport conditions were not always conducive to observing an upwelling event. This would result in annual fluxes of $\geq 206 \pm 151 \mathrm{Gmol} \mathrm{yr}^{-1}$ for $\mathrm{CO}_{2}$, $\geq-1.6 \pm 1.1 \mathrm{Tmol} \mathrm{yr}^{-1}$ for $\mathrm{O}_{2}, \geq 272 \pm 248 \mathrm{Mmol} \mathrm{yr}^{-1}$ for $\mathrm{N}_{2} \mathrm{O}$, and $\geq 3.3 \pm 2.8 \mathrm{Gmol} \mathrm{yr}^{-1}$ for $\mathrm{CH}_{4}$ from upwelling events.

Such an estimate for $\mathrm{CO}_{2}$ is substantial when compared to the net flux that Laruelle et al. (2014) estimated of $-424.9 \mathrm{Gmol} \mathrm{yr}^{-1}$ for the entire Benguela region or the $-141.5 \mathrm{Gmol} \mathrm{yr}^{-1}$ found by Gregor and Monteiro (2013) for the southern Benguela. A high flux of $\mathrm{CO}_{2}$ is possible due to the higher wind speeds and the more remineralized character of the South Atlantic Central Water that upwells at Lüderitz. Using inverse methods, Gruber et al. (2001) constrained the net flux of oxygen for the temperate South Atlantic (an area of $1.5 \times 10^{7} \mathrm{~km}^{2}$ ) to be $15.5 \mathrm{Tmol} \mathrm{yr}^{-1}$, which suggests that upwelling events in the Lüderitz region could be regionally significant. An annual source of this magnitude for $\mathrm{N}_{2} \mathrm{O}$ is modest when compared to the budgetary calculations of other coastal regions. As the global coastal upwelling source of $\mathrm{N}_{2} \mathrm{O}$ is estimated to be $7140 \mathrm{Mmol} \mathrm{yr}^{-1}$ (Nevison et al., 2004), the emissions for the Lüderitz-Walvis Bay region would represent $3.2 \%$ of the area but only $1.7 \%$ of these emissions. For $\mathrm{CH}_{4}$ this approximation is 2 to 3 times higher than the net evasion from the Arabian Sea (Bange et al., 1998) and 10 to 20 times greater than the annual release of $\mathrm{CH}_{4}$ from the entire Mauritanian upwelling system (Kock et al., 2008; Brown et al., 2014), but modest when compared to the estimate of Monteiro (2010) for the entire Benguela Upwelling System, $56 \mathrm{Gmol} \mathrm{yr}^{-1}$, or the $10 \mathrm{Gmol} \mathrm{yr}^{-1}$ proposed by Emeis et al. (2018) for the NBUS.

A full regional top-down quantification of the annual fluxes - as opposed to the event-based averages we present here - of the Benguela from land-based atmospheric measurements would require additional efforts, such as a Bayesian synthesis inversion of the data, where a prior surface flux field is adjusted to best match the atmospheric observations. This approach relies on an accurate knowledge of atmospheric transport and ideally a dense network of mea- 
surement sites. Currently there are only two such sites in the Benguela region known to the authors, NDAO and Cape Point Observatory (CPT) in South Africa. Until the observational coverage is improved, uncertainties will remain large. Given the cost and labor involved in measuring fluxes in situ with a research vessel, it seems advantageous to pursue a denser network of regional sites along the southwestern coast of southern Africa. Such data would be of use to ongoing efforts to accurately determine terrestrial and marine greenhouse gas budgets for the region (e.g., Valentini et al., 2014; Bange et al., 2019).

In other EBUS, monitoring of some or all of atmospheric $\mathrm{CO}_{2}, \mathrm{CH}_{4}, \mathrm{~N}_{2} \mathrm{O}$, and $\delta\left(\mathrm{O}_{2} / \mathrm{N}_{2}\right)$ is ongoing. Most of these sites are flask sampling locations, which are not as suitable as continuous measurements for capturing the shortlived nature of upwelling events. The California Current System is probably the best sampled, through two Advanced Global Atmospheric Gases Experiment (AGAGE) sites and numerous NOAA/ESRL activities. Long-term measurements are also made at the Cape Verde Atmospheric Observatory off the Mauritanian upwelling region. While these efforts are extremely valuable, a greater density of continuous atmospheric measurement sites could provide great benefit in quantifying greenhouse gas fluxes from upwelling systems.

\section{Summary and conclusions}

We have shown that coastal atmospheric anomalies of $\mathrm{CO}_{2}$, $\mathrm{O}_{2}, \mathrm{~N}_{2} \mathrm{O}$, and $\mathrm{CH}_{4}$ can be related to upwelling events in the Lüderitz and Walvis Bay upwelling cells. Using a simple model, we have estimated the flux density of the four species during upwelling events. These top-down estimates of surface fluxes have been found to be in reasonable agreement with in situ surface flux densities as determined from shipboard measurements, although the top-down method underestimates the flux density before the model was tuned. Our study highlights the usefulness of continuous monitoring in order to achieve a more accurate estimation of the emissions of GHGs from coastal upwelling systems, since the large impact of small temporal and spatial scales of variability is prone to be overlooked by in situ surveys.

The Lüderitz and Walvis Bay upwelling cells have been shown to potentially be an unusually large source of $\mathrm{CH}_{4}$ to the atmosphere for the marine environment. In contrast, the region is a weaker source of $\mathrm{N}_{2} \mathrm{O}$ compared to other upwelling regions, a fact which has been predicted from modeling studies and noted in observations of dissolved concentrations and air-sea fluxes. This upwelling area also functions as a significant source term in the $\mathrm{CO}_{2}$ budget of the Benguela Current.

We have focused here on upwelling events, because they are distinguishable from other sources of intraseasonal variability in the atmospheric record. A full top-down accounting of the greenhouse gas budget of the Benguela could be ac- complished through a Bayesian atmospheric inversion of one or more coastal stations. Based on our results and previous studies (Nevison et al., 2004; Lueker et al., 2003), we suggest establishing a network of high-resolution atmospheric GHG measurements adjacent to major coastal upwelling regions in order to monitor their GHG emissions. Continuous land-based monitoring will help to establish time series of coastal GHG fluxes which are needed to account for the seasonal variability and to detect both short-term and long-term trends of both marine and terrestrial coastal GHG emissions.

Data availability. Atmospheric data from NDAO are included as part of the supporting information. M99 $\mathrm{N}_{2} \mathrm{O}$ data are available from the PANGAEA Open Access library (Arévalo-Martínez and Bange, 2019) and $\mathrm{CO}_{2}$ data will be submitted to the Surface Ocean $\mathrm{CO}_{2}$ Atlas (SOCAT, https://www.socat.info/, last access: 16 October 2019).

Supplement. The supplement related to this article is available online at: https://doi.org/10.5194/bg-16-4065-2019-supplement.

Author contributions. MH and JVL conceived of the location and motivation for the atmospheric observatory. EJM, JVL, and TS conducted the atmospheric observations in Namibia of all species and on the RV Meteor for $\mathrm{CO}_{2}, \mathrm{CH}_{4}$, and $\delta\left(\mathrm{O}_{2} / \mathrm{N}_{2}\right)$. DLAM and TS made the underway measurements of the other dissolved and atmospheric gases on the Meteor. EJM wrote the manuscript, and all the authors made substantial contributions to the text and/or analyses.

Competing interests. The authors declare that they have no conflict of interest.

Acknowledgements. The authors wish to express their gratitude to the Master, crew, and Chief Scientist (Detlef Quadfasel) of the RV Meteor during leg M99 and to the government of Namibia for permission to work in Namibian territorial waters. This work is a contribution to SOPRAN III (BMBF grant no. FKZ 03F0662). SATRE collaborators Gregor Rehder and Jan Werner (Leibniz Institute for Baltic Sea Research) operated the $\mathrm{N}_{2} \mathrm{O} / \mathrm{CO} / \mathrm{CO}_{2}$ underway system throughout the cruise. Tim Rixen (Leibniz Center for Tropical Marine Ecology/University of Hamburg) kindly provided the FRS Africana cruise data as well as helpful comments on this paper. We also thank and acknowledge Gillian Maggs-Kölling, Theo Wassenaar, Jessica Sack, Tayler Chicoine, Robert Logan, and the Gobabeb community for their technical support and hospitality. The authors are grateful for the efforts and expertise of Armin Jordan, Willi Brand, Michael Hielscher, Bert Steinberg, Johannes Schwarz, and Jürgen Richter (MPI-BGC) in preparing and analyzing flask samples and gas cylinders. Author Damian L. Arévalo-Martínez was supported by EU FP7 project InGOS (grant agreement no. 284274). Author Eric J. Morgan was a part of the International Max Planck Research School for Global Biogeochemical Cycles when this work was conducted and acknowledges its funding and support. 
Funding for the research activities presented here was provided by the Max Planck Society.

Financial support. The article processing charges for this openaccess publication were covered by the Max Planck Society.

Review statement. This paper was edited by S. Wajih A. Naqvi and reviewed by two anonymous referees.

\section{References}

Amante, C. and Eakins, B.: ETOPO1 1 Arc-Minute Global Relief Model: Procedures, Data Sources and Analysis, NOAA Technical Memorandum NESDIS NGDC-24. National Geophysical Data Center, NOAA, https://doi.org/10.7289/V5C8276M, 2009.

Aoki, N., Ishidoya, S., Matsumoto, N., Watanabe, T., Shimosaka, T., and Murayama, S.: Preparation of primary standard mixtures for atmospheric oxygen measurements with less than $1 \mu \mathrm{mol} \mathrm{mol}^{-1}$ uncertainty for oxygen molar fractions, Atmos. Meas. Tech., 12, 2631-2646, https://doi.org/10.5194/amt-12-2631-2019, 2019.

Arévalo-Martínez, D., Kock, A., Steinhoff, T., Brandt, P., Dengler, M., Fischer, T., Körtzinger, A., and Bange, H. W.: Nitrous oxide during the onset of the Atlantic cold tongue, J. Geophys. Res.Ocean., 122, 171-184, https://doi.org/10.1002/2016JC012238, 2017

Arévalo-Martínez, D. L., Beyer, M., Krumbholz, M., Piller, I., Kock, A., Steinhoff, T., Körtzinger, A., and Bange, H. W.: A new method for continuous measurements of oceanic and atmospheric $\mathrm{N}_{2} \mathrm{O}$, CO and $\mathrm{CO}_{2}$ : performance of off-axis integrated cavity output spectroscopy (OA-ICOS) coupled to nondispersive infrared detection (NDIR), Ocean Sci., 9, 1071-1087, https://doi.org/10.5194/os-9-1071-2013, 2013.

Arévalo-Martínez, D. L., Kock, A., Löscher, C. R., Schmitz, R. A., and Bange, H.: Massive nitrous oxide emissions from the tropical South Pacific Ocean, Nat. Geosci., 8, 530-533, 2015.

Arévalo-Martínez, D. L., Steinhoff, T., Brandt, P., Körtzinger, A., Lamont, T., Rehder, G., and Bange, H. W.: $\mathrm{N}_{2} \mathrm{O}$ emissions from the northern Benguela upwelling system, Geophys. Res. Lett., 46, 3317-3326, https://doi.org/10.1029/2018GL081648, 2019.

Arévalo-Martínez, D. L. and Bange, H. W.: High Resolution Underway Nitrous Oxide Measurements (water) during METEOR cruise M99, PANGAEA, https://doi.org/10.1594/PANGAEA.902507, 2019.

Babbin, A., Bianchi, D., Jayakumar, A., and Ward, B.: Rapid nitrous oxide cycling in the suboxic ocean, Science, 348, 1127-1130, 2015.

Bange, H., Ramesh, R., Rapsomanikis, S., and Andreae, M.: Methane in surface waters of the Arabian Sea, Geophys. Res. Lett., 25, 3547-3550, 1998 .

Bange, H., Andreae, M., Lal, S., Law, C., Naqvi, S., Patra, P., Rixen, T., and Upstill-Goddard, R.: Nitrous oxide emissions from the Arabian Sea: A synthesis, Atmos. Chem. Phys., 1, 61-71, https://doi.org/10.5194/acp-1-61-2001, 2001.

Bange, H., Bell, T., Cornejo, M., Freing, A., Uher, G., UpstillGoddard, R., and Zhang, G.: MEMENTO: a proposal to develop a database of marine nitrous oxide and methane measurements,
Environ. Chem., 6, 195-197, https://doi.org/10.1071/EN09033, 2009.

Bange, H. W., Arévalo-Martínez, D. L., de la Paz, M., Farías, L., Kaiser, J., Kock, A., Law, C. S., Rees, A. P., Rehder, G., Tortell, P. D., Upstill-Goddard, R. C., and Wilson, S. T.: A Harmonized Nitrous Oxide $\left(\mathrm{N}_{2} \mathrm{O}\right)$ Ocean Observation Network for the 21st Century, Front. Mar. Sci., 6, 157, https://doi.org/10.3389/fmars.2019.00157, 2019.

Bianchi, D., Dunne, J., Sarmiento, J., and Galbraith, E.: Data-based estimates of suboxia, denitrification, and $\mathrm{N}_{2} \mathrm{O}$ production in the ocean and their sensitivities to dissolved $\mathrm{O}_{2}$, Global Biogeochem. Cy., 26, GB2009, https://doi.org/10.1029/2011GB004209, 2012.

Blanke, B., Speich, S., Bentamy, A., Roy, C., and Sow, B.: Modeling the structure and variability of the southern Benguela upwelling using QuikSCAT wind forcing, J. Geophys. Res.-Ocean., 110, C07018, https://doi.org/10.1029/2004JC002529, 2005.

Bopp, L., Le Quéré, C., Heimann, M., Manning, A., and Monfray, P.: Strong $\mathrm{CO}_{2}$ emissions from the Arabian Sea during South-West Monsoon, Global Biogeochem. Cy., 16, 1022, https://doi.org/10.1029/2001GB001445, 2002.

Brand, W.: $\mathrm{O}_{2} / \mathrm{N}_{2}$ Storage Aspects and Open Split Mass Spectrometric Determination, in: Proceedings of the 12th WMO/IAEA Meeting of Experts on Carbon Dioxide, Other Greenhouse Gases and Related Tracers Measurement Techniques, WMO/TD-No. 1275, edited by: Worthy, D. and Huang, L., WMO, Geneva, Switzerland, 145-150, 2005.

Brown, I., Torres, R., and Rees, A.: The origin of sub-surface source waters define the sea-air flux of methane in the Mauritanian Upwelling, NW Africa, Dynam. Atmos. Oceans, 67, 39-46, 2014.

Brüchert, V., Currie, B., Peard, K., Lass, U., Endler, R., Dübecke, A., Julies, E., Leipe, T., and Zitzmann, S.: Biogeochemical and Physical Control on Shelf Anoxia and Water Column Hydrogen Sulphide in the Benguela Coastal Upwelling System Off Namibia, in: Past and Present Water Column Anoxia, edited by: Neretin, L., Springer, the Netherlands, 161-193, 2006.

Brüchert, V., Currie, B., and Peard, K.: Hydrogen sulphide and methane emissions on the central Namibian shelf, Prog. Oceanogr., 83, 169-179, 2009.

Cao, Z., Dai, M., Evans, W., Gan, J., and Feely, R.: Diagnosing $\mathrm{CO}_{2}$ fluxes in the upwelling system off the Oregon-California coast, Biogeosciences, 11, 6341-6354, https://doi.org/10.5194/bg-116341-2014, 2014.

Capone, D. and Hutchins, D.: Microbial biogeochemistry of coastal upwelling regimes in a changing ocean, Nat. Geosci., 6, 711717, https://doi.org/10.1038/ngeo1916, 2013.

Carter, B., Feely, R., Williams, N., Dickson, A., Fong, M., and Takeshita, Y.: Updated methods for global locally interpolated estimation of alkalinity, $\mathrm{pH}$, and nitrate, Limnol. Oceanogr.Method., 16, 119-131, https://doi.org/10.1002/lom3.10232, 2018.

Cohen, Y. and Gordon, L.: Nitrous Oxide Production in the Ocean, J. Geophys. Res., 84, 347-353, 1979.

Cornejo, M., Farías, L., and Paulmier, A.: Temporal variability in $\mathrm{N}_{2} \mathrm{O}$ water content and its air-sea exchange in an upwelling area off central Chile (36 ${ }^{\circ}$ S), Mar. Chem., 101, 85-94, 2006.

Dee, D., Uppala, S., Simmons, A., Berrisfold, P., Poli, P., Kobayashi, S., Andrea, U., Balmaseda, A., Balsamo, G., Bauer, P., Bechtold, P., Beljaars, A., van de Berg, L., Bidlot, J., Bor- 
mann, N., Delsol, C., Dragani, R., Fuentes, M., Geer, A., Haimberger, L., Healy, S., Hersbach, H., Hólm, E., Isaksen, L., Kållberg, P., Köhler, M., Matricardi, M., McNally, A., Monge-Sanz, B., Morcrette, J.-J., Park, B.-K., Peubey, C., de Rosnay, P., Tavolato, C., Thépaut, J.-N., and Vitart, F.: The ERA-Interim reanalysis: configuration and performance of the data assimilation system, Q. J. Roy. Meteor. Soc., 137, 553-597, 1979.

Demarcq, H., Barlow, R., and Hutchings, L.: Application of a chlorophyll index derived from satellite data to investigate the variability of phytoplankton in the Benguela system, Afr. J. Mar. Sci., 29, 271-282, 2007.

Desbiolles, F., Blanke, B., and Bentamy, A.: Short-term upwelling events at the western African coast related to synoptic atmospheric structures as derived from satellite observations, J. Geophys. Res.-Ocean., 119, 1-23, https://doi.org/10.1002/2013JC009278, 2014a.

Desbiolles, F., Blanke, B., Bentamy, A., and Grima, N.: Origin of fine-scale wind stress curl structures in the Benguela and Canary upwelling systems, J. Geophys. Res.-Ocean., 119, 7931-7948, https://doi.org/10.1002/2014JC010015, 2014b.

Dillon, M. B., Lamanna, M. S., Schade, G. W., Goldstein, A. H., and Cohen, R. C.: Chemical evolution of the Sacramento urban plume: Transport and oxidation, J. Geophys. Res., 107, 4045, https://doi.org/10.1029/2001jd000969, 2002.

Draxler, R. and Hess, G.: Description of the HYSPLIT4 modeling system, Tech. Rep., NOAA Tech. Memo. ERL ARL-224, NOAA Air Resources Laboratory, Silver Spring, MD, USA, 28 pp., 1997.

Draxler, R. and Hess, G.: An overview of the HYSPLIT4 modelling system for trajectories, dispersion and deposition, Aust. Meteorol. Mag., 47, 295-308, 1998.

Emeis, K., Eggert, A., Flohr, A., Lahajnar, N., Nausch, G., Neumann, A., Rixen, T., Schmidt, M., Van der Plas, A., and Wasmund, N.: Biogeochemical processes and turnover rates in the Northern Benguela Upwelling System, J. Mar. Syst., 188, 63-80, https://doi.org/10.1016/j.jmarsys.2017.10.001, 2018.

Emeis, K.-C., Brüchert, V., Currie, B., Endler, R., Ferdelman, T., Kiessling, A., Leipe, T., Noli-Peard, K., Struck, U., and Vogt, T.: Shallow gas in shelf sediments of the Namibian coastal upwelling ecosystem, Cont. Shelf Res., 24, 627-642, 2004.

Evans, W., Hales, B., and Strutton, P.: Seasonal cycle of surface ocean $p \mathrm{CO}_{2}$ on the Oregon shelf, J. Geophys. Res., 116, C05012, https://doi.org/10.1029/2010JC006625, 2011.

Evans, W., Hales, B., Strutton, P., Shearman, R., and Barth, J.: Failure to bloom: Intense upwelling results in negligible phytoplankton response and prolonged $\mathrm{CO}_{2}$ outgassing over the Oregon shelf, J. Geophys. Res.-Ocean., 120, 1446-1461, https://doi.org/10.1002/2014JC010580, 2015.

Eyring, H.: Viscosity, Plasticity, and Diffusion as Examples of Absolute Reaction Rates, J. Chem. Phys., 4, 283-291, 1936.

Ferrell, R. and Himmelblau, D.: Diffusion Coefficients of Nitrogen and Oxygen in Water, J. Chem. Eng. Data, 12, 111-115, 1967.

Frame, C., Deal, E., Nevison, C., and Casciotti, K.: $\mathrm{N}_{2} \mathrm{O}$ production in the eastern South Atlantic: Analysis of $\mathrm{N}_{2} \mathrm{O}$ stable isotopic and concentration data, Global Biogeochem. Cy., 28, 1262 1278, https://doi.org/10.1002/2013GB004790, 2014.

Garbe, C., Rutgersson, A., Boutin, J., de Leeuw, G., Delille, B., Fairall, C., Gruber, N., Hare, J., Ho, D., Johnson, M., Nightingale, P., Pettersson, H., Piskozub, J., Sahlée, E., Tsai, W.-T.,
Ward, B., Woolf, D., and Zappa, C.: Transfer Across the Air-Sea Interface, in: Ocean-Atmosphere Interactions of Gases and Particles, edited by: Liss, P. and Johnson, M., Springer, Heidelberg, Germany, 55-112, 2014.

García, H. and Gordon, L.: Oxygen solubility in seawater: Better fitting equations, Limnol. Oceanogr., 37, 1307-1312, 1992.

González-Dávila, M., Santana-Casiano, J., and Ucha, I.: Seasonal variability of $f \mathrm{CO}_{2}$ in the Angola-Benguela region, Prog. Oceanogr., 83, 124-133, 2009.

Goubanova, K., Illig, S., Machu, E., Garçon, V., and Dewitte, B.: SST subseasonal variability in the central Benguela upwelling system as inferred from satellite observations (1999-2009), J. Geophys. Res.-Ocean., 118, 4092-4110, https://doi.org/10.1002/jgrc.20287, 2013.

Gregor, L. and Monteiro, P.: Is the southern Benguela a significant regional sink of $\mathrm{CO}_{2}$ ?, S. Afr. J. Sci., 109, 5 pp. https://doi.org/10.1590/sajs.2013/20120094, 2013.

Gruber, N., Gloor, M., Fan, S.-M., and Sarmiento, J.: Air-sea flux of oxygen estimated from bulk data: Implications for the marine and atmospheric oxygen cycles, Global Biogeochem. Cy., 15, 783803, 2001.

Gutknecht, E., Dadou, I., Le Vu, B., Cambon, G., Sudre, J., Garçon, V., Machu, E., Rixen, T., Kock, A., Flohr, A., Paulmier, A., and Lavik, G.: Coupled physical/biogeochemical modeling including $\mathrm{O}_{2}$-dependent processes in the Eastern Boundary Upwelling Systems: application in the Benguela, Biogeosciences, 10, 35593591, https://doi.org/10.5194/bg-10-3559-2013, $2013 \mathrm{a}$.

Gutknecht, E., Dadou, I., Marchesiello, P., Cambon, G., Le Vu, B., Sudre, J., Garçon, V., Machu, E., Rixen, T., Kock, A., Flohr, A., Paulmier, A., and Lavik, G.: Nitrogen transfers off Walvis Bay: a 3-D coupled physical/biogeochemical modeling approach in the Namibian upwelling system, Biogeosciences, 10, 41174135, https://doi.org/10.5194/bg-10-4117-2013, 2013 b.

Hagen, E., Feistel, R., Agenbag, J., and Ohde, T.: Seasonal and interannual changes in Intense Benguela Upwelling (1982-1999), Oceanol. Acta, 24, 557-568, 2001.

Hardman-Mountford, N., Richardson, A., Agenbag, J., Hagen, E., Nykjaer, L., Shillington, F., and Villacastin, C.: Ocean climate of the South East Atlantic observed from satellite data and wind models, Prog. Oceanogr., 59, 181-221, 2003.

Hutchings, L., van der Lingen, C., Shannon, L., Crawford, R., Verheye, H., Bartholomae, C., van der Plas, A., Louw, D., Kreiner, A., Ostrowski, M., Fidel, Q., Barlow, R. G., Lamont, T., Coetzee, J., Shillington, F., Veitch, J., Currie, J. C., and Monteiro, P.: The Benguela Current: An ecosystem of four components, Prog. Oceanogr., 83, 15-32, 2009.

Jacob, D.: Introduction to Atmospheric Chemistry, Princeton University Press, Princeton, NJ, 267 pp., 1999.

Jähne, B., Heinz, G., and Dietrich, W.: Measurement of the Diffusion Coefficients of Sparingly Soluble Gases in Water, J. Geophys. Res., 92, 10767-10776, 1987.

Justus, C. and Mikhail, A.: Height variation of wind speed and wind distributions statistics, Geophys. Res. Lett., 3, 261-264, 1976.

Keeling, R. and Shertz, S.: Seasonal and interannual variations in atmospheric oxygen and implications for the global carbon cycle, Nature, 358, 723-727, 1992.

Kock, A. and Bange, H. W.: Counting the Ocean's Greenhouse Gas Emissions, Eos, 96, 10-13, https://doi.org/10.1029/2015eo023665, 2015. 
Kock, A., Gebhardt, S., and Bange, H. W.: Methane emissions from the upwelling area off Mauritania (NW Africa), Biogeosciences, 5, 1119-1125, https://doi.org/10.5194/bg-5-1119-2008, 2008.

Laliberté, M.: Model for Calculating the Viscosity of Aqueous Solutions, J. Chem. Eng. Data, 52, 321-335, 2007.

Landwehr, S., Miller, S. D., Smith, M. J., Saltzman, E. S., and Ward, B.: Analysis of the PKT correction for direct $\mathrm{CO}_{2}$ flux measurements over the ocean, Atmos. Chem. Phys., 14, 3361-3372, https://doi.org/10.5194/acp-14-3361-2014, 2014.

Laruelle, G., Lauerwald, R., Pfeil, B., and Regnier, P.: Regionalized global budget of the $\mathrm{CO}_{2}$ exchange at the air-water interface in continental shelf seas, Geophys. Res. Lett., 28, 1199-1214, https://doi.org/10.1002/2014GB004832, 2014.

Levin, L., Liu, K., Emeis, K.-C., Breitburg, D., Cloern, J., Deutsch, C., Giani, M., Goffart, A., Hofmann, E., Lachkar, Z., Limburg, K., Liu, S.-M., Montes, E., Naqvi, W., Ragueneau, O., Rabouille, C., Sarkar, S., Swaney, D., Wassman, P., and Wishner, K.: Comparative biogeochemistry-ecosystem-human interactions on dynamic continental margins, J. Mar. Syst., 141, 3-17, https://doi.org/10.1016/j.jmarsys.2014.04.016, 2015.

Loucaides, S., Tyrrell, T., Achterberg, E., Torres, R., Nightingale, P., Kitidis, V., Serret, P., Woodward, M., and Robinson, C.: Biological and physical forcing of carbonate chemistry in an upwelling filament off northwest Africa: Results from a Lagrangian study, Global Biogeochem. Cy., 26, GB3008, https://doi.org/10.1029/2011GB004216, 2012.

Lueker, T. J.: Coastal upwelling fluxes of $\mathrm{O}_{2}, \mathrm{~N}_{2} \mathrm{O}$, and $\mathrm{CO}_{2}$ assessed from continuous atmospheric observations at Trinidad, California, Biogeosciences, 1, 101-111, https://doi.org/10.5194/bg-1-101-2004, 2004.

Lueker, T., Walker, S., Vollmer, M., Keeling, R., Nevison, C., and Weiss, R.: Coastal Upwelling air-sea fluxes revealed in atmospheric observations of $\mathrm{O}_{2} / \mathrm{N}_{2}, \mathrm{CO}_{2}$ and $\mathrm{N}_{2} \mathrm{O}$, Geophys. Res. Lett., 30, 1292, https://doi.org/10.1029/2002GL016615, 2003.

Lutjeharms, J. and Meeuwis, J.: The extent and variability of SouthEast Atlantic upwelling, S. Afr. J. Mar. Sci., 5, 51-62, 1987.

Mackay, D. and Shiu, W.: A Critical Review of Henry's Law Constants for Chemicals of Environmental Interest, J. Phys. Chem. Ref. Data, 10, 1175-1199, 1981.

Manizza, M., Keeling, R., and Nevsion, C.: On the processes controlling the seasonal cycles of the air-sea fluxes of $\mathrm{O}_{2}$ and $\mathrm{N}_{2} \mathrm{O}$ : A modelling study, Tellus B, 64, 18429, https://doi.org/10.3402/tellusb.v64i0.18429, 2012.

Maritorena, S. and Siegel, D.: Consistent merging of satellite ocean color data sets using a bio-optical model, Remote Sens. Environ., 94, 429-440, 2005.

McGillis, W., Edson, J., Ware, J., Dacey, J., Hare, J., Fairall, C., and Wanninkhof, R.: Carbon dioxide flux techniques performed during GasEx-98, Mar. Chem., 75, 267-280, 2001.

Millero, F. J. and Huang, F.: The density of seawater as a function of salinity ( 5 to $70 \mathrm{~g} \mathrm{~kg}^{-1}$ ) and temperature (273.15 to 363.15 K), Ocean Sci., 5, 91-100, https://doi.org/10.5194/os-591-2009, 2009.

Millero, F., Graham, T., Huang, F., Bustos-Serrano, H., and Pierrot, D.: Dissociation constants of carbonic acid in seawater as a function of salinity and temperature, Mar. Chem., 100, 80-94, https://doi.org/10.1016/j.marchem.2005.12.001, 2006.

Monteiro, P.: The Benguela Current System, in: Carbon and Nutrient Fluxes in Continental Margins: A Global Synthesis, edited by: Liu, K., Atkinson, L., Quiniones, R., and Talue-McManus, L., Springer, Berlin, 65-78, 2010.

Monteiro, P., van der Plas, A., Mohrholz, V., Mabille, E., Pascall, A., and Joubert, W.: Variability of natural hypoxia and methane in a coastal upwelling system: Oceanic physics or shelf biology?, Geophys. Res. Lett., 33, L16614, https://doi.org/10.1029/2006GL026234, 2006.

Morgan, E.: Continuous Measurements of Greenhouse Gases and Atmospheric Oxygen in the Namib Desert, Ph.D. thesis, Christian-Albrechts-Universität zu Kiel, 187 pp., 2015.

Morgan, E. J., Lavrič, J. V., Seifert, T., Chicoine, T., Day, A., Gomez, J., Logan, R., Sack, J., Shuuya, T., Uushona, E. G., Vincent, K., Schultz, U., Brunke, E.-G., Labuschagne, C., Thompson, R. L., Schmidt, S., Manning, A. C., and Heimann, M.: Continuous measurements of greenhouse gases and atmospheric oxygen at the Namib Desert Atmospheric Observatory, Atmos. Meas. Tech., 8, 2233-2250, https://doi.org/10.5194/amt-8-22332015, 2015.

Naqvi, S., Bange, H., Farías, L., Monteiro, P., Scranton, M., and Zhang, J.: Marine hypoxia/anoxia as a source of $\mathrm{CH}_{4}$ and $\mathrm{N}_{2} \mathrm{O}$, Biogeosciences, 7, 2159-2190, https://doi.org/10.5194/bg7-2159-2010, 2010.

Nevison, C., Butler, J., and Elkins, J.: Global distribution of $\mathrm{N}_{2} \mathrm{O}$ and the $\Delta \mathrm{N}_{2} \mathrm{O}-\mathrm{AOU}$ yield in the subsurface ocean, Global Biogeochem. Cy., 17, 1119, https://doi.org/10.1029/2003GB002068, 2003.

Nevison, C., Lueker, T., and Weiss, R.: Quantifying the nitrous oxide source from coastal upwelling, Global Biogeochem. Cy., 18, GB1018, https://doi.org/10.1029/2003GB002110, 2004.

Nevison, C., Keeling, R., Weiss, R., Popp, B., Jin, X., Fraser, P., Porter, L., and Hess, P.: Southern Ocean ventilation inferred from seasonal cycles of atmospheric $\mathrm{N}_{2} \mathrm{O}$ and $\mathrm{O}_{2} / \mathrm{N}_{2}$ at Cape Grim, Tasmania, Tellus B, 57, 218-229, 2005.

Peard, K.: Seasonal and Interannual Variability of Wind-Driven Upwelling at Lüderitz, Namibia, Master's thesis, University of Cape Town, 108 pp., 2007.

Pierrot, D., Neill, C., Sullivan, K., Castle, R., Wanninkhof, R., Lüger, H., Johannessen, T., Olsen, A., Feely, R., and Cosca, C.: Recommendations for autonomous underway $p \mathrm{CO}_{2}$ measuring systems and data-reduction routines, Deep-Sea Res. Pt. II, 56, 512-522, https://doi.org/10.1016/j.dsr2.2008.12.005, 2009.

Price, H., Jaffe, D., Cooper, O., and Doskey, P.: Photochemistry, ozone production, and dilution during longrange transport episodes from Eurasia to the northwest United States, J. Geophys. Res., 109, D23S13, https://doi.org/10.1029/2003JD004400, 2004.

Rehder, G., Collier, R., Heeschen, K., Kosro, P., Barth, J., and Suess, E.: Enhanced marine $\mathrm{CH}_{4}$ emissions to the atmosphere off Oregon caused by coastal upwelling, Global Biogeochem. Cy., 16, 1081, https://doi.org/10.1029/2000GB001391, 2002.

Reimer, J., Vargas, R., Smith, S., Lara-Lara, R., Gaxiola-Castro, G., Hernández-Ayón, J., Castro, A., Escoto-Rodriguez, M., and Martínez-Osuna, J.: Air-sea $\mathrm{CO}_{2}$ fluxes in the near-shore and intertidal zones influenced by the California Current, J. Geophys. Res.-Ocean., 118, 1-16, 2013.

Risien, C., Reason, C., Shillington, F., and Chelton, D.: Variability in satellite winds over the Benguela upwelling system during 1999-2000, J. Geophys. Res., 109, C03010, https://doi.org/10.1029/2003JC001880, 2004. 
Rödenbeck, C., Quéré, L., Heimann, M., and Keeling, R.: Interannual variability in oceanic biogeochemical processes inferred by inversion of atmospheric $\mathrm{O}_{2} / \mathrm{N}_{2}$ and $\mathrm{CO}_{2}$ data, Tellus $\mathrm{B}, 60$, 685-705, 2008.

Roobaert, A., Laruelle, G. G., Landschützer, P., and Regnier, P.: Uncertainty in the global oceanic $\mathrm{CO}_{2}$ uptake induced by wind forcing: quantification and spatial analysis, Biogeosciences, 15, 1701-1720, https://doi.org/10.5194/bg-15-1701-2018, 2018.

Sansone, F., Popp, B., Gasc, A., Graham, A., and Rust, T.: Highly elevated methane in the eastern tropical North Pacific and associated isotopically enriched fluxes to the atmosphere, Geophys. Res. Lett., 28, 4567-4570, https://doi.org/10.1029/2001GL013460, 2001.

Santana-Casiano, J., González-Dávila, M., and Ucha, I.: Carbon dioxide fluxes in the Benguela upwelling system during winter and spring: A comparison between 2005 and 2006, Deep-Sea Res. Pt. II, 56, 533-541, 2009.

Scranton, M. and Farrington, J.: Methane Production in the Waters off Walvis Bay, J. Geophys. Res., 82, 4947-4953, 1977.

Severinghaus, J.: Studies of the terrestrial $\mathrm{O}_{2}$ and carbon cycles in sand dune gases and in Biosphere 2, Ph.D. thesis, Columbia University, 148 pp., 1995.

Stephens, B., Keeling, R., Heimann, M., Six, K., Murnane, R., and Caldeira, K.: Testing global ocean carbon cycle models using measurements of atmospheric $\mathrm{O}_{2}$ and $\mathrm{CO}_{2}$ concentration, Global Biogeochem. Cy., 12, 213-230, 1998.

Suntharalingam, P. and Sarmiento, J.: Factors governing the oceanic nitrous oxide distribution: Simulations with an ocean general circulation model, Global Biogeochem. Cy., 14, 429-454, 2000.

Thompson, R., Manning, A., Lowe, D., and Weatherburn, D.: A ship-based methodology for high precision atmospheric oxygen measurements and its application in the Southern Ocean region, Tellus, 59, 643-653, 2007.

Torres, R., Turner, D., Silva, N., and Rutllant, J.: High short-term variability of $\mathrm{CO}_{2}$ fluxes during an upwelling event off the Chilean coast at $30^{\circ} \mathrm{S}$, Deep-Sea Res. Pt. I, 46, 1161-1179, 1999.

Trimmer, M., Chronopoulou, P.-M., Maanoja, S., Upstill-Goddard, R., Kitidis, V., and Purdy, K.: Nitrous oxide as a function of oyxgen and archaeal gene abundance in the North Pacific, Nat. Commun., 7, 13451, https://doi.org/10.1038/ncomms13451, 2016.
Valentini, R., Arneth, A., Bombelli, A., Castaldi, S., Cazzolla Gatti, R., Chevallier, F., Ciais, P., Grieco, E., Hartmann, J., Henry, M., Houghton, R. A., Jung, M., Kutsch, W. L., Malhi, Y., Mayorga, E., Merbold, L., Murray-Tortarolo, G., Papale, D., Peylin, P., Poulter, B., Raymond, P. A., Santini, M., Sitch, S., Vaglio Laurin, G., van der Werf, G. R., Williams, C. A., and Scholes, R. J.: A full greenhouse gases budget of Africa: synthesis, uncertainties, and vulnerabilities, Biogeosciences, 11, 381-407, https://doi.org/10.5194/bg-11-381-2014, 2014.

van der Plas, A., Monteiro, P., and Pascall, A.: Cross-shelf biogeochemical characteristics of sediments in the central Benguela and their relationship to overlying water column hypoxia, Afr. J. Mar. Sci.e, 29, 37-47, 2007.

Veitch, J., Penven, P., and Shillington, F.: The Benguela: A laboratory for comparative modeling studies, Prog. Oceanogr., 83, 296-302, 2009.

Walter, S., Bange, H., Breitenbach, U., and Wallace, D.: Nitrous oxide in the North Atlantic Ocean, Biogeosciences, 3, 607-619, https://doi.org/10.5194/bg-3-607-2006, 2006.

Wanninkhof, R.: Relationship Between Wind Speed and Gas Exchange Over the Ocean, J. Geophys. Res., 92, 7373-7382, 1992.

Wanninkhof, R.: Relationship between wind speed and gas exchange over the ocean revisited, Limnol. Oceanogr.-Method., 12, 351-362, 2014.

Weiss, R.: Carbon Dioxide in Water and Seawater: The Solubility of a Non-Ideal Gas, Mar. Chem., 2, 203-215, 1974.

Weiss, R. and Price, B.: Nitrous Oxide Solubility in Water and Seawater, Mar. Chem., 8, 347-359, 1980.

Yamagishi, H., Tohjima, Y., Mukai, H., and Sasaoka, K.: Detection of regional scale sea-to-air oxygen emission related to spring bloom near Japan by using in-situ measurements of the atmospheric oxygen/nitrogen ratio, Atmos. Chem. Phys., 8, 33253335, https://doi.org/10.5194/acp-8-3325-2008, 2008. 